UDC 7.07:929 Timotijević M.

https://doi.org/10.18485/ms_zmskij.2021.69.1.10

Иван Негришорац

\title{
ИСТРАЖИВАЧКИ НЕМИРИ И ИСКУШЕЊА МИРОСЛАВА ТИМОТИЈЕВИЋА: КА СЕМИОТИЦИ СРПСКЕ КУЛТУРЕ
}

Аутор разматра научни опус историчара уметности Мирослава Тимотијевића и констатује релевантност тог опуса за шири скуп друштвених и хуманистичких наука, а посебно за семиотику српске културе. Тај научни опус он преиспитује унутар различитих проблемских, па и теоријско-методолошких поља које је, у посебним фазама свога развоја, Тимотијевић отварао на изузетно занимљив и провокативан начин. Један круг његових студија сачињавају монографије о српским црквама и манастирима (Црква Свет̄ов Георіија у Темищвару, 1996; Манасӣир Крущееоол, 2008), а у том погледу Тимотијевић следи основне идеје Павла Флоренског о семиотичкој сложености цракава и манастира, а уважава и раније доприносе српских научника у том домену (Вељко Петровић, Милан Кашанин, Војислав Ј. Ђурић, Дејан Медаковић, Војислав Кораћ и др.), као и домете модерне науке о уметности, Други круг се односи на историографску синтезу у проучавању српског барокног сликарства

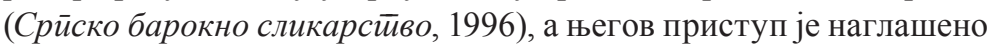
теоријски, поетички и иконографски оријентисан, чак са извесним елементима оног типа стилских анализа које се могу довести у везу и са идејом Хајнриха Велфлина о уметничкој историји ‘без имена'. Трећи проблемски круг везан је за истраживање историје свакодневног живота и приватности у српској култури XVIII века (Рађа-

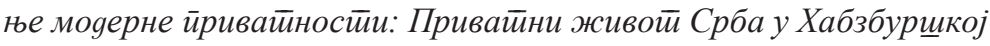
монархији о краја 17. яо йочейка 19. века, 2006), којим се овај историчар уметности, својим драгоценим доприносом придружио оним српским историчарима који су ишли трагом истраживачких путева и програма Филипа Аријеса и Жоржа Дибија. Од те књиге Тимотијевић се, међутим, опредељује за терминолошка решења која не можемо оценити као напредак у проучавању осетљиве проблематике настајања народа и нација: традиционалнији концепт који 
подразумева тријаду појмова ‘етничка маса', ‘народ’ и ‘нација' аутор текста сматра много примеренијим и оперативнијим него што је то бинарни модел 'етнија' и 'нација' којем се Тимотијевић сасвим приклонио. Онај први, тријадни модел је прилагођен епоси која настоји да очувао разноликости света, док је овај други, бинарни модел примеренији епоси која хоће да обави унификацију света, те да поништи лепоту разлика за које епоха глобализације више нема слуха. Четврти проблемски круг везан је за културу и политику сећања, а Тимотијевић је начинио специфичну студију једног случаја везаног за обележавање празника Српске Цвети (Таковски устйнак-Сриске Цветии: О јавном заједничком сећаюу и заборављаюу у симболичкој йолитиици званичне рейрезенйайивне кулииуре, 2012) показујући како се државном политиком утврђује не само феномен сећања него и феномен заборављања унутар репрезентативне културе неке друштвене заједнице. И коначно, пети проблемски круг који је својим монографијама покрио Мирослав Тимотијевић односи се на проучавање опуса једног великог сликара барокне епохе (Теоgор Крачун, 2019), епохе којој је овај драгоцени истраживач посветио највећи део своје истраживачке пажње. У свим овим проблемским пољима овај историчар уметности је увек откривао скривене могућности иновирања сазнајног поступка и напретка теоријско-методолошког облика мишљења. Због тога, а посебно због сазнања до којих је својим истраживањима долазио, Мирослав Тимотијевић ће у једној свеобухватној семиотици српске културе заузимати веома важно и драгоцено место.

Кључне речи: сликарство, уметност, историја уметности, цркве и манастири, барок, народ, нација, етничка маса, етнија, историја приватности, култура и политика сећања, теорија и методологија, друштвене и хуманистичке науке, семиотика српске културе.

Мирослав Тимотијевић (1950-2016) јесте, одиста, једна лепа реткост и необична драгоценост српског не само историјско-уметничког него и, шире посматрано, друштвено-хуманистичког научног амбијента. Превасходно историчар уметности, он је у својој струци и науци градио обрасце поузданог, утемељеног и сазнајно веома подстицајног истраживања, али је истовремено опрезно и промишљено градио искораке изван досегнутог теоријско-методолошког оквира, настојећи да струку отвори ка знатно ширим историографским просторима. А на тим ширим истраживачким просторима указале су се перспективе у којима се још интензивније могу сагледати линије сусретања и прожимања уметности и других облика креативности. Можда је управо ова последња чињеница она која ме је охрабрила да и ја, као човек посвећен како песничком и књижевном стваралаштву тако и њиховом, превасходно теоријском, критичком и историјском проучавању, смогнем 
снаге да искажем оно поштовање које осећам за нешто старијег, прерано отишлог колегу, историчара уметности Мирослава Тимотијевића.

Озбиљне импликације изучавања културе у најширем смислу, импликације које је његов научни опус не само нужно садржавао него и непрестано у развојном смислу подстицао, отварају широк простор промишљања његовог дела не само у искључивим оквирима историје уметности него и историје српске културе уопште. Отуда сматрам да суочавање са његовим истраживачким пољима, сазнајним дометима и теоријско-методолошким искушењима може бити драгоцено и за културолошка истраживања најширег могућег спектра, укључујући и простор истраживања књижевности. У томе препознајем нешто што се најпрецизније може именовати семиотиком српске културе, а то је област у којој јасно видим велики значај укупног опуса Мирослава Тимотијевића. Истовремено то је и област у којој се сусрећу проучаваоци српске историје, фолклора, књижевности, језика, обичаја, менталитетских образаца, уметности, облика сазнања и вредновања света, као и свега онога што можемо обухватити појмом културе у најширем смислу. На том пространом, али врло осетљивом подручју истраживачи из врло различитих струка имају шта да кажу једни другима или једни о другима.

1. ТЕОРИЈСКА И МЕТОДОЛОШКА ШИРИНА. Прво ШТо ваља УочитИ У УКуПном научном опусу Мирослава Тимотијевића јесте необична теоријска ширина и методолошка разноврсност коју је овај истраживач исказивао. Његова главна дела се теоријско-методолошки тако међусобно разликују да можемо уочити заступљеност неколико основних модела проучавања: аутор се никако није задовољавао само једним могућим типом приступа феномену уметности, а кад би досегао изразитост неког од методских поступака он би потом настојао да изгради такве иновације које би нешто битно помериле у начину разумевања не само одређених типова уметничких дела него и феномена уметности уопште. То настојање је често укључивало и такво проширење методолошког поља у којем, у том проширењу, битно се мења начин теоријског сагледавања појма уметности и културе. Његов укупни стваралачки опус је, стога, садржавао извесну концептуалну логику и развојну путању која показује и доказује да је реч о одиста несмиреној истраживачкој радозналости која је непрестано трагала за променама и разликама у начину конституисања предмета проучавања. Таква теоријско-методолошка ширина и динамика јесте сама по себи изразита и несумњива вредност. Она, неспорно, сведочи о ауторској свести о томе да се никаквим, ма колико усавршаваним монистичким облицима приступа не може до краја исцрпети феномен уметности него да се само разноврсним, плуралистичким моделима разумевања и тумачења могу начинити важни кораци унапређења свеукупног сазнања уметности и културе.

Већ један лаки и летимични поглед на оне најважније Тимотијевићеве студије показују колико су тачне изнесене констатације. Један ток његових истраживања водио је ка сагледавању уметничке комплексности и обухват- 
ности црквеног живота и храма као сложених уметничких и семиотичких целина. На таквом облику концептуализације предмета истраживања утемељена су два велика истраживачка резултата која је Мирослав Тимотијевић остварио: реч је о књигама Црква свет̄ов Георйија у Темищвару (Матица српска, Нови Сад 1996) и Манасӣир Круще gол 1-2 (ИК „Драганић“- -Покрајински завод за заштиту споменика културе Војводине, Београд - Нови Сад 2008). Ове две књиге свакако представљају узорни облик првог Тимотијевићевог теоријско-методолошког обрасца, а он је показао како ваља обављати истраживања свих оних аспеката које укључује тако сложен културни и семиотички феномен као што је црква или манастир. Методолошки посматрано такав феномен је подразумевао веома различит низ поступака и изграђених посебних вештина, а све њих је Мирослав Тимотијевић имао у свом стваралачком хабитусу у више него довољној мери, па су сазнајни резултати овог његовог подухвата веома високи и надасве поуздани.

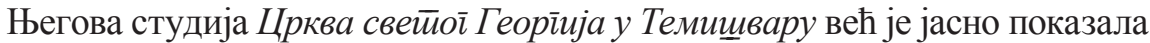
један специфични облик обједињавања различитих методских процедура и херменеутичких способности. С једне стране, тај истраживачки подухват је укључивао спремност на стрпљиви архивски рад и решавање читавог низа питања која се појављују у хоризонту чисто документарног и фактичког стања ствари, а самим тим и, условно речено, неопозитивистичког разумевања уметности, па је у том погледу Тимотијевић веома успешно решавао проблеме као што су реконструкција оснивања црквене општине, опис постепене изградње цркве, ширење црквено-општинског здања и читав низ послова везаних за разноврсне функције српске цркве у темишварском предграђу званом Фабрика. Скрупулозност са којом је Тимотијевић истраживао мноштво докумената довела је до поузданих и непобитних сазнања после којих престају свака нагађања и олако изречене оцене којима су били склони они који не знају како стоје ствари. Методолошки циљ оваквих истраживања везан је првенствено за утврђивање чињеница, а њих је истраживач тако конституисао да се после ове књиге може рећи како је потпуно заокружена читава прича о једној од трију српских цркава у Темишвару (остале две су Саборна црква Вазнесења Господњег у самом центру града и Црква светог Николе у Мехали), и то на најозбиљнији, строго научан, чак неопозитивистички прецизно дефинисан начин. Могућа су, дакако, нека нова сазнања о појединостима овог уметничког споменика, али је у основи чињенично и документарно истраживање обављено тако да му приговора, бар за сада, нема. Могу се нова сазнања свему томе додавати и на њих се надограђивати, али тешко да би се шта ту могло озбиљније оспорити или померити.

С друге стране, израда ове монографије подразумевала је и изразиту ауторову способност херменеутичког захвата у саму уметничку, па и ширу семиотичку супстанцу ове цркве, пре свега иконостаса, икона и зидног сликарства (у средишту пажње су, дакако, радови Николе Нешковића), али и многих других артефаката црквеног ентеријера, а поготово свега онога што се чува у ризници: путири, окована јеванђеља, кивот, петохлебница, 
крстови, кадионице, кандила, чираци, рипиде, плаштанице, свештеничке одежде, рукописне књиге, иконе, портрети и сл. Методолошки циљ оваквих истраживања далек је од сваког облика неопозитивистичке опсесије чињеницама, а аутор се удубљује у начине разумевања и тумачења ликовног језика, те посебних семантичких ефеката насталих у специфичностима ових артефаката препознатих на фону шире схваћене српске православне црквене уметности, посебно оне развијане у Хабзбуршком царству. На основу таквог споја двеју, помало опречних методолошких путања, Мирослав Тимотијевић је и могао да допре до моћних научних увида, као што је могао и да констатује како поменути храм „није локална парохијска црква, него један од истакнутих споменика српског народа у Румунији““(Тимотијевић 1996а: 181). Овакав закључак делује сасвим уопштено, али кад се зна шта је све њему претходило, онда је та уопштеност, задобивши изузетно чврсту и стабилну подлогу, постала савршено аргументована и чак непорецива.

Највише домете у бављењу феноменима цркава, тј. манастира Тимотијевић је остварио у монографији Манасӣир Круще gол. Следећи ригорозни образац који је изградио у студији о храму у темишварској Фабрици, он је у потоњој студији приступио манастиру који поседује невероватно богатство најразличитијих артефаката, докумената и сведочанстава, и то оних од највећег културног и националног значаја. У одабиру теме, чинило се да је аутор поступио на крајње рационалан и промишљен начин, поштујући истовремено и сопствену потребу за све већим стваралачким изазовима. Његова развојна путања ишла је несумњиво добром, узлазном линијом: од једне темишварске, градске, тачније приградске и периферијске цркве несумњивог значаја он је кренуо ка великом манастиру и задужбини светородне, владарске лозе Бранковића, тј. дошао је до храма од највећег значаја за националну културу. У том смислу, није случајно то што је Тимотијевић одабрао без сумње најважнији фрушкогорски манастир са најбогатијом и најсложенијом, такорећи неисцрпном истраживачком грађом; уз то, треба имати на уму и чињеницу да је тај манастир један од кључних семиотичких феномена изразито везаних управо за период барока, чији је Тимотијевић водећи проучавалац у српској историји уметности.

Изради ове студије претходили су многи други радови истога аутора, како они који су се односили на деспотску породицу Бранковића (ТимотиЈевић 1991-1992), тако и радови о природи српског барокног сликарства, црквене уметности, те начина живота и рађања приватности у 18. веку (Тимотијевић 1996б; 2006), па је из таквог фундуса знања аутор могао да се креће у мноштво различитих праваца и рукаваца сопствених истраживања. У студији о манастиру Крушедолу, још потпуније него у монографији о фабричкој цркви Светог Георгија, манифестовала се теоријско-методолошка ширина и спрема, те префињена херменеутичка вештина Мирослава Тимотијевића. Поступно ширећи сазнајне перспективе, аутор се кретао од историјских реконструкција манастира као духовног и културног центра (по-

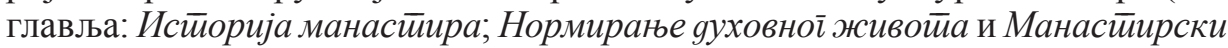


комйлекс), преко структурног описа манастира као семиотичке целине (Keлијско зуање, Тойоїрафија келијскоі здања, Архитекекичра храма, Сйаро зияно

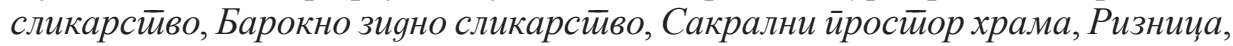
Библиоиека), па до специфичне културе сећања која се у манастиру или поводом њега отелотворује (Кулит и сећање, Срйски йаниееон). Но, да би дошао до те концептуалне ширине, истраживач је морао да прихвати чињеницу о сукобу два могуће концепције у разумевању манастира као феномена - једне концепције која је везана за општу меморијалну функцију овог манастира светородне лозе Бранковића („Меморијална улога Крушедола у јавном заједничком сећању постајала је временом све сложенија, па се манастир од последњих деценија XIX назива 'Српски Пантеон'“; Тимотијевит 2008: 9) и друге која је везана за појаву критичке историографије, а која сложене манастирске функције своди на пуки чињенички простор сачињен од неколико позитивистички проверљивих сазнајних поља („Рађањем критичке историографије, од Димитрија и Илариона Руварца надаље, идеализована представа о манастиру постепено се замењује објективнијом, али и знатно редукованијом сликом. Манастирски комплекс се лишава своје идејне суштине и постаје нека врста позитивистичког историографског трезора“; Тимотијевић 2008: 9). Аутор је, дакле, потпуно свестан сукоба између оваква два истраживачка концепта.

Ни једна ни друга перспектива није за Тимотијевића безрезервно прихватљива, па он трага за нечим што назива „новом културном историјом“, а она би се заснивала „на потреби превазилажења уобичајених класификаторских подела на научне дисциплине и тежњи ка свеобухватнијем и целовитијем тумачењу прошлости и њених феномена“ (Тимотијевић 2008: 9). У концептуалној поставци везаној за разумевање манастира у свеколикој његовој функционалној сложености, Тимотијевић се изричито, али сасвим узгредно, позива на доприносе Павла Флоренског, тврдећи да „свеобухватној структури изучавања манастира, коју је пре једног века замислио Павле Флоренски, скоро да и није могуће много додати“ (Тимотијевић 2008: 9). У својој студији Тимотијевић помиње Флоренског још само на једном месту, и то у фусноти, без додатних описа и коментара, и без навођења конкретног наслова, али са указивањем на библиографски извор. На том месту аутор студије о манастиру Крушедолу каже: „На потребу да се манастир протумачи као сложени христијанизовани микрокосмос указао је Павле Флоренски у једном предавању о Светотројичкој сергијевској лаври, које је знатно касније објављено: П. Флоренский, Сочинения, II, Москва 1996, 762-763“ (Тимотијевић 2008: 99). Познаваоцу дела Павла Флоренског не би, међутим, представљало посебну тешкоћу да идентификује текст о којем је реч: тај

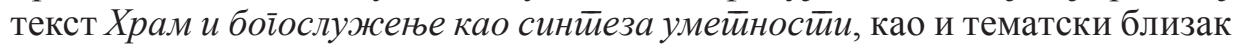
текст Тројице-Серіијева лавра (в. ФЛоренски 2004: 123-153), већ су и на српски били преведени у време када је студија о Крушедолу Мирослава Тимотијевића писана и објављивана. Необична је чињеница да се за Тимитојевићеву књигу концептуално тако важан текст Павла Флоренског некако гура 
на маргину, у једва уочљиво сенку, те да се име овог руског изузетног теолога и семиотичара не помиње чак ни на списку основне литературе.

Такав гест хотимичног смештања заслужног мислиоца какав је Флоренски у простор ћутње и тишине садржи врло јаке, индикативне импликације и мора објективног читаоца да наведе на извесна додатна промишљања. Чини се, по свему судећи, да је Мирослав Тимотијевић био сасвим подељен у времену писања студије о Крушедолу: с једне стране, несумњиво је Флоренски, па и моћна руска богословско-философска мисаона традиција (и то не она барокна!) указала на управо онакав концепт манастира и црквене уметности као својеврсне семиотичке синтезе, али је, с друге стране, у контексту наглашено секуларних друштава и култура Запада, са све очигледнијим атеизмом, антитеизмом и нихилизмом, све изразитија постала чињеница како таква мисао о присутности живога Бога постајао крајње непријатном за оне мислиоце који су доживљај живога Бога заувек изгубили. У том смислу је за Тимотијевића Флоренски постао помало непријатан сведок на којег и није баш упутно позивати се у пуној мери: интелектуално је он извор концептуапне снаге, али је као есенцијални, теоцентрични мислилац он постао идеолошки у великој мери неприхватљив и непожељан. А како се буде ширио свеопшти глобалистички занос, схваћен као незаустављиви тријумф Запада у свим сферама не само економског, политичког и војног него и мисаоног и интелектуалног живота, тако ће се све више распростирати потреба да се многи 'незгодни сведоци' сведу прво на сасвим тихо, готово невидљиво присуство, а онда и да се постепено пребаце у простор ћутње у мери у којој се нова, глобалистичка мисао технички буде укључивала, па и постепено сасвим освајала терен какав је пре тога био могућ захваљујући искључиво духовној снази несводивој на материјалне чиниоце стварности. То је, иначе, општа формула империјалне епистемологије Запада која настоји све просторе интелектуалне моћи да запоседне, чак и онда, а нарочито онда, када она сама нема аутентичне снаге мисли која би такво запоседање могла да изведе. Мирослав Тимотијевић је био спреман да у овакве процесе уђе, а колике је то размере добило видеће се из књига насталих после књиге о Крушедолу.

Сама студија Манастиир Круще gол предузела је једну, истраживачки изузетно важну и племениту обавезу, а то је да - сасвим у духу идеја Павла Флоренског - манастир прикаже као „жив организам, који се у свом трајању непрестано развија и мења“, али тако да он остаје „у материјалном смислу отелотворење идеје“ (Тимотијевић 2008: 10). Посебан проблем је то што је овај манастир непрестано руиниран и пљачкан, а нарочито у време Независне Државе Хрватске, па је аутор морао много тога додатно да реконструише на темељу артефаката и истраживања везаних за неке сасвим друге објекте, места, људе и догађаје. Најтежи задатак је био управо то, а аутор га формулише на следећи начин: „Тежња да у скоро испражњени манастир идејно 'вратимо' бар део онога што му је некада припадало приморала нас је на заморно пописивање инвентарских бројева наведених у белешкама, што се није могло избећи. Био је то једини начин да будућим истраживачима Крушедола 
олакшамо трагање и идентификацију предмета некадашњег манастирског 'орната', без кога није могуће схватити његов унутрашњи садржај, нити смисао“ (Тимотијевић 2008: 11). Извођење оваквих задатака и поставки био је веома комплексан посао, а Мирослав Тимотијевић све то обавио на изузетно убедљив начин који остаје за неке будуће истраживачке провере, па и, условно речено, за вечита времена. Уза све то, чињеница је да су предмети Тимотијевићевих херменеутичких коментара и анализа били такође веома сложени, у распону од радова непознатих сликара из XVI и XVII века, па све до добро познатих, каснијих сликара XVIII века попут Јова Василијевића, Стефана Тенецког, Димитрија Бачевића и др. На тај начин добили смо концептуално веома широк, изворној идеји сасвим уподобљен, а сазнајно заокружен и детаљан, историјски подробан опис најважнијег фрушкогорског манастира и свих феномена који су са њим повезани.

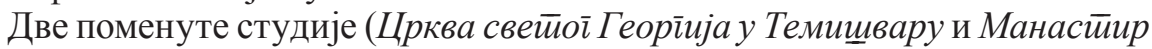
Круще gол) следиле су веома комплексан образац за истраживање појединих цркава и манастира, па је у том жанровском пољу Тимотијевић, без сумње, досегао сами врх у српској историји уметности. Тај врх, истина, већ су на нивоу основног стандарда успоставили неки други, изузетно заслужни проучаваоци српских манастира и цркава, махом са простора Старе Србије, Косова и Метохије, те Свете Горе: Димитрије Богдановић, Војислав Ј. Ђурић, Дејан Медаковић, Хиланgар, Бгд 1978; Гордана Бабић, Војислав Кораћ, Сима

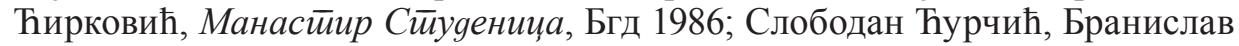
Тодић, Грачаница, Бгд 1988; Војислав Ј. Ђурић, Сима Ћирковић, Војислав Ко-

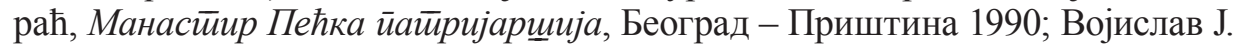
Ђурић, Сойоћани, Београд - Приштина 1991; Милка Чанак Медић, Бранислав Тодић, Манастичр Дечани, Бгд 2005. и др. Мирослав Тимотијевић је пак показао како и у оквиру таквог, већ успостављеног методолошког обрасца, досегнути облици истраживања могу итекако даље да се померају и да се новим сазнајним перспективама досегну простори највише научне креативности.

Други теоријско-методолошки образац, па и поступак досезања и превазилажења освојених врхова Тимотијевић је веома јасно и убедљиво демонстрирао у домену исписивања уметничко-историјске синтезе којом је приказана читава једна епоха у развоју уметности. Реч је, дакако, о његовој монографији Срӣско барокно сликарсӣво (Матица српска, Нови Сад 1996), монографији која је на сјајан начин објединила и надградила сазнања његових великих претходника попут Вељка Петровића, Милана Кашанина, Павла Васића, Миодрага Коларића, Дејана Медаковића, Миодрага Јовановића, Динка Давидова и других. У Предговору својој студији Тимотијевић,

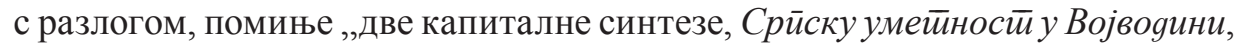
коју су 1927. написали Вељко Петровић и Милан Кашанин, и Срӣску умей-

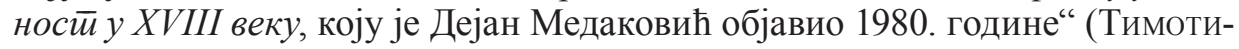
ЈЕвић 1996б: 9). У том Предговору аутор истиче и то да је његова студија настала као докторска дисертација, одбрањена на Филозофском факултету у Београду 1993. године, и то пред комисијом у којој су били одиста врхун- 
ски зналци и истраживачи као што су Дејан Медаковић, Сретен Петковић и ментор Миодраг Јовановић. Чак и у односу на Медаковићеве изузетне, у сваком погледу узорне домете у истраживању барокне уметности, Тимотијевић јесте досегнуо истински нови квалитет после којег се ова и оваква изучавања напросто морају рачунати као новоуспостављена традицијска подлога и стандард у односу на који треба тражити нове путеве. И по ширини и обухватности грађе, али нарочито по методолошкој доследности и убедљивости, Мирослав Тимотијевић је начинио изванредно, иновативно и незаборавно дело, а оно јесте повремено доживљавало озбиљне надоградње (на пример, истраживања Владимира Симића у области историје уметничких идеја, те посебних облика функционисања визуелне културе), али њена барокно-историографска конструкција није озбиљније померена. Стога, и после више од четврт века од изласка, ова Тимотијевићева синтетичка расправа још није добила могућу замену, а утисак је да се тако нешто неће скоро десити, те да је њена актуелност и даље потпуно неспорна. ${ }^{1}$

Студија Срйско барокно сликарсӣво је, осим уводних и закључних разматрања, обухватила три групе питања. Прва група питања отворила је историјску и комуникациону слику феномена, указујући на развојне чиниоце читаве епохе, од проблема сликара и наручилаца, те њихових сложених односа, преко разматрања функција барокне слике, закључно са развојном схемом од раног, преко високог, па до касног барока, а све то је укључило и однос барока према традиционалном сликарству. Други проблемски круг концентрисан је на основним питањима барокне поетике и одговарајућег стила, и то у распону од њихове нормативности и реторичности, преко значајне улоге слике и сликовитости, алегорије и амблематике, па све до наглашене историчности у схватању света и човека. Трећи део ове важне студије посвећен је барокној иконографији, а највише начину приказивања богословских тема, од Свете Тројице и анђела, преко приказа Исуса Христа и Богомајке, па све до многих светаца, те исказивања догматског, схоластичког програма и одговарајућих моралистичких схватања. У овој монографији аутор посвећује велику пажњу најважнијим сликарима (Јов Василијевић, Христофор Џефаровић / Жефаровић, Василије Романович, Стефан Тенецки, Василије Остојић, Димитрије Бачевић, Никола Нешковић, Димитрије Поповић, Јован Четиревић Грабован, Јанко Халкозовић, Јован Поповић, Теодор Крачун, Захарија Орфелин, Јаков Орфелин, Теодор Илић Чешљар и др.), али су опажања о овим сликарским опусима више усмерена ка поетичком нивоу расправе, док је знатно мање тај покушај тежио ка изградњи читавих портрета значајних уметника.

Имајући све ове чињенице на уму, могли бисмо закључити да је Тимотијевић много ближи концепту стилистичких истраживања и изградње уметничке историје „без имена“ Хајнриха Велфлина² него што се ослања

${ }^{1} \mathrm{O}$ томе сведочи и појава другог издања ове књиге, код истог издавача, 2020. године.

2 У том смислу би и Тимотијевић могао потписати реченице које је 1888. године Велфлин записао у Предговору првог издања своје књиге Ренесанса и барок: Истираживағе 
на стандардну, не само неопозитивистичку него и било коју другу истраживачку процедуру усмерену ка утврђивању позиције аутора и препознавању утицаја биографских фактора у стваралачком чину. Истина је да Тимотијевић редовно помиње имена идентификованих аутора, па у том смислу и не настоји да развије потпуни Велфлинов историографски идеал, али је очигледно да је његов начин мишљења махом усмерен ка поетичким општостима, идејним структурама и стилским анализама које припадају феномену барокне епохе. У науци о књижевности те идеје слабљења фигуре аутора су, после стилистичких подстицаја Х. Велфлина, Оскара Валцела и др. теоретичара из прве половине XX века, постале посебно актуелне од краја 60-их година, када је дошло и до објаве „Смрти аутора“ (1968) Ролана Барта, ${ }^{3}$ те до развоја методолошких покушаја реактуелизације позиције читаоца (немачка теорија рецепције, америчка reader-reasponce criticism, тј. критика читалачке реакције и сл.). Наравно, лако можемо утврдити да се на овакве токове критичко-теоријског мишљења Мирослав Тимотијевић није непосредно ослањао, али је исто тако лако показати колико он са њима јесте био у истинском дослуху.

2. ИЗУЧАВАњЕ ПРИВАТНОСТИ И ЖИВОТ КАО УМЕТНОСТ. Трагом оваквих идеја и несумњиве истраживачко-концептуалне динамике, Мирослав Тимотијевић је, рекао бих, сасвим природно дошао и до свог трећег теоријско-методолошког обрасца, тј. до историографског концепта истраживања свакодневног и приватног живота. У том погледу је он подстицај примио од француске историографије која је, нарочито од почетка 80-их година XX века, са концептуалним иницијативама Филипа Аријеса и његовог млађег сарадника Жоржа Дибија, одлучно кренула у истраживање историје приватности, и то не само у новом веку и модерном добу, где је то најпримереније и најближе облицима људске самосвести тога типа, него и у целокупној историји западне цивилизације. Из оваквог програма истраживања, а захваљујући широ-

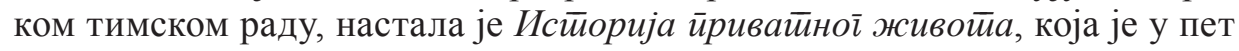

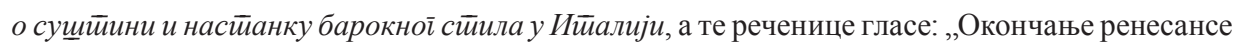
је тема истраживања које следи. Оно треба да буде прилог историји стилова, а не историји уметника. Моја намера је била да уочим симптоме опадања и да у ,подивљалости и самовољи“ препознам, ако је могуће, закон који ће допустити увид у унутрашњи живот уметности“ (ВЕлфлин 2000: 5). Овај напор да се историја стила или, у новијој теоријској интерпретацији - историја семиотичких система стави у средиште истраживачке пажње, несумњиво јесте важна одлика Тимотијевићевог разумевања историје уметности и културе.

3 У том контексту Барт у поменутом есеју закључује: „Тако је откривена потпуна егзистенција писања; текст је сачињен од многоструких писања, изведен из разних култура, те улази у међусобне односе дијалога, пародије, оспоравања, но постоји једно мјесто гдје та многострукост налази своје жариште, а то мјесто је читатељ, а не, као што се досада говорило, аутор. Читатељ је простор на којему су сви цитати који чине писање записани, а да при томе ни један од њих није изгубљен; јединство текста не лежи у његову поријеклу него у његову одредишту. Но то одредиште више не може бити особно; он је једноставно онај нетко који садржи на једном мјесту све трагове од којих се писани текст састоји“ (БАРт 1986: 179-180). 
томова приказала како се на читавом европском простору „бију битке (...) између мушкараца и жена, између старих и младих, између газде и послуге“, те како се „најпре у већим, па у мањим градовима, и само за мушкарце, приватни простор разделио на троје: дом, у коме је конфинирано женско постојање; место пословне активности које је такође приватизовано - радионица, радња, канцеларија, фабрика; и, најзад, забран какав је кафана или клуб, онако како то одговара мушком саучесништву или отпочинку“ (Диьи 2000: 7). Реч је, дакако, о историјском процесу веома дугог трајања који недвосмислено заслужује помна, али методолошки веома рафинирана историографска истраживања.

Непосредни повод за проучавање приватности у српском друштву XVIII века Мирослав Тимотијевић је, по свему судећи, добио унутар тима историографа (предводила га је Смиља Марјановић - Душанић) окупљених око издавачке куће Клио из Београда. Ова кућа је, у оквиру свог веома добро осмишљеног издавачког програма у области историографије, кренула да

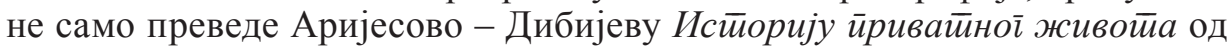
римскога царства до наших дана (књиге су излазиле у периоду 2000-2004) него и да организује рад једног тима стручњака који би написао историју српског приватног живота. Тако су настале изузетно вредне и подстицајне студије: Смиља Марјановић-Душанић и Даница Поповић (прир.), Привайни живот̄ у срйским земљама среgњеї века (2004), Александар Фотић (прир.),

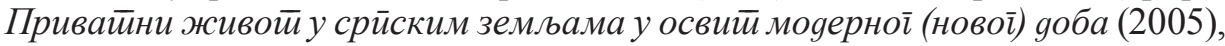

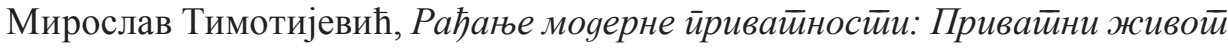
Срба у Хабзбуршккој монархији оg краја 17. gо йочейка 19. века (2006), Ана

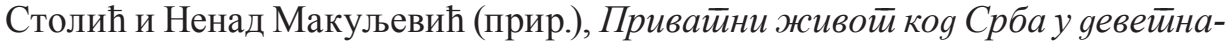

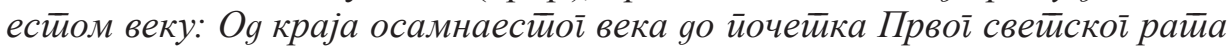

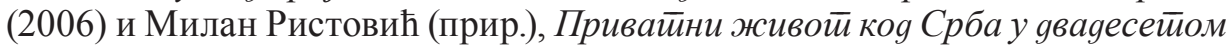
веку (2007). Томе ваља придодати и једну скраћену верзију ове целине, верзију коју ауторски потписују Марко Поповић, Мирослав Тимотијевић и

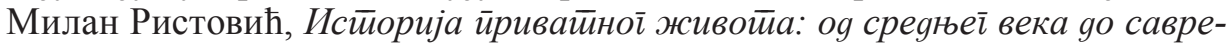
меної gоба, а та књига је изашла 2011. године.

Ове књиге специфичног предметног и методолошког усмерења, по свему судећи, нису могли да напишу само наши историографи у ужем смислу (они су превасходно били оријентисани ка облицима јавног живота, и то углавном у области политичких, војних и државно-правних односа), па су им се у овом подухвату прикључивали углавном историчари уметности и визуелне културе, попут Мирослава Тимотијевића или Ненада Макуљевића, или археолози попут Марка Поповића. Занимљиво је, мећутим, констатовати да су све ове студије дело тимског рада, а једина књига која је индивидуално ауторско дело јесте управо студија Мирослава Тимотијевића о рађању српске приватности у XVIII веку. Уз то ваља приметити да је у књизи коју је приредио А. Фотић, аутор готово четвртине текстова управо Мирослав Тимотијевић. Те чињенице довољно говоре колико је овај аутор и методолошки, а и у погледу суштинског увида у истраживану грађу, био спреман за 
овакву врсту подухвата за коју су, у случају других векова и епоха, по правилу ангажовани читави тимови стручњака. Све то је могло да се деси превасходно стога што се у својим истраживањима историје српске уметности XVIII века Тимотијевић није ограничио само на анализу ликовних дела него је настојао да изучи и свеукупну сложеност социјалног и културног контекста, па је тако акумулирао широко и пребогато знање из различитих културолошких области. На тај начин је постао спреман да изнутра сагледа и начин живота, уобичајене сукобе и потребу за смиреношћу духа појединца и породице, специфичну динамику мањих социјалних група и целине људске заједнице, посебност амбијената цркава и манастира, грађанских породица, професионалних и стручних удружања, културних друштава и сл. Таква врста широких информација била му је веома корисна у истраживању уметности тога периода, а сада се, са новим методолошким покретима у историографији, показало да су та сазнања добродошла и у једном ширем подручју истраживања изван саме уметности, тј. у социјалном простору који се могао посматрати као нека врста, уметности сасвим аналогних, организованих семиотичких целина. Зато с разлогом истраживања Мирослава Тимотијевића видим као најозбиљнији допринос ономе што сам назвао семиотиком српске културе.

Концептуално посматрано Тимотијевић се највише ослањао на становиште Филипа Аријеса, махом оно које је он изложио у свом програмском

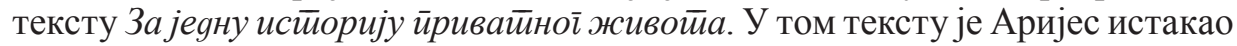
да истраживање појаве приватности после средњега века подразумева осветљавање трију крупних политичко-културних догађаја у европској историји: промењена улога државе, развитак писмености и ширење књиге, као и

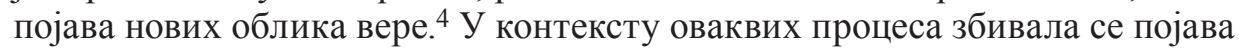
приватности, а за њено прецизније детектовање потребно би било, по Аријесу, користити читав „,аналитички репертоар“ појмова помоћу којих можемо пратити развојне токове тих процеса. У те појмове он уврштава следеће појаве: литература о лепом понашању, аутографска књижевност о самом субјекту који пише, склоност ка усамљивању, односи пријатељства, подешавање свакодневног живота, те промене у кући као животном простору и сл. Назначени развојни процеси подразумевају „три значајне фазе“: освајање појединачне приватности, појава група за дружења и промене у начину функционисања породице. Захваљујући овом Аријесовом програмском тексту, као и његовој реализацији у колективном истраживачком подухвату

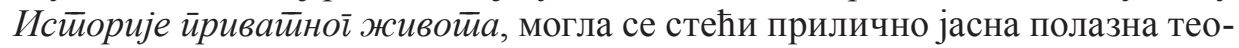
ријска позиција, као и методолошко усмерење на један специфичан концепт стварности и на групе чињеница које су тим концептом идентификоване.

Захваљујући Аријесовом упутству истраживачи долазе до увида како од краја XVII и почетка XVIII века ,јавно је постало деприватизовано“, ,jавна ствар више се не може побркати с приватним имањем или интересом“,

${ }^{4}$ О томе видети, нав. текст, у АРијеС - Диьи 2002: 7-9. 
а „тај ослобођени простор попуниће породица“ (АријеС - Диьи 2002: 19). Истовремено Аријес упозорава да се оваква истраживања морају концентрисати на два аспекта: с једне стране, предмет истраживања мора постати „супротност између државног службеника и појединца и односа између подручја државе и онога што ће постати, у крајњем случају, домаћи простор“; с друге стране, предмет истраживања мора постати све оно што „односи се на дружење и на прелаз с анонимног дружења, где се бркају појмови јавног и приватног, на развијено дружење, при чему се појављују потпуно раздвојена подручја: остатак анонимног дружења, професионално подручје, и једна област, такође приватна, која се своди на живот у домаћинству“ (АРИјеС Диьи 2002: 19). Као што се и из наведених редова може закључити, Аријесов текст је веома концизан, али су методолошка упутства савршено, можда и превише јасна, чак и кад нису до детаља изведена.

Мирослав Тимотијевић је потпуно свестан колико Аријесово теоријско-методолошко полазиште и јесте и није употребљиво у истраживању проблема приватног живота у српској историји. То полазиште није употребљиво у, примера ради, истраживању средњовековља и раног новог века, а тај део посла је тим, на челу са Смиљом Марјановић - Душанић, морао да обави са пуним ослонцем „на резултате истраживача ове проблематике у византијском и османском цивилизацијском кругу“, а не западноевропском (в. Тимотијевић 2006: 7). За разлику од својих колега - претходника, Тимотијевић је у потпуности могао да се ослони на Аријесова упутства јер је реч о епоси у којој су Срби управо ушли у сферу западноевропских и средњоевропских сфера утицаја. Поменутим упутствима је Тимотијевић додао још неколико важних упоришних тачака везаних махом за историју философије, а у том погледу он помиње и Декарта, Канта, Русоа, Хердера и др. (Тимотијевић 2006: 10). Осим тога, он веома прецизно упућује свога читаоца на чињеницу да његова стратегија „усмерена је на расветљавање односа између модерне приватности и приватног живота, два блиска, али не и истоветна појма. Под приватношћу подразумевамо стање свести о приватном, а под приватним животом примену те свести у свакодневици. Однос та два појма, од којих први припада историји свести а други историји материјалне културе, чинио је сажимајуће јединство“ (Тимотијевић 2006: 10-11). Већ из уводног дела књиге, јасно се може видети како је у теоријско-методолошком смислу своја истраживања Тимотијевић веома пажљиво припремао.

Истоветну пажњу он је посветио и композицији своје књиге, а целину излагања поделио је у седам поглавља. У првом поглављу размотрио је појединца у функцији верника и поданика, односно описао је процесе верских и државних реформи. У другом поглављу је изложио увиде у појаву нове индивидуалности, а то подразумева успостављање јаснога разликовања јавне и приватне сфере, као и појаве потребе за самоћом и отуђењем. У трећем поглављу је предмет разматрања везан за човекову телесност, и то како за доживљаје телесних задовољстава тако и за доживљај трошности тела. У четвртом поглављу аутор разматра проблем „скровитости душе“, и то како 
наглашено субјективистичке доживљаје тако и доживљаје настале из суочења појединца са продуктима писане културе. Највећи део књиге аутор је посветио породици и породичном животу, па је у петом поглављу описао породичну заједницу у српском друштву XVIII века, и то како улоге мушкарца, тако и жена и деце. Шесто поглавље посвећено је опису породичног дома, тј. простора у којем се одвија породични живот, док је у седмом, завршном поглављу описан шири облик приватности који укључује дружење људи изван породичног амбијента, те излазак у јавност, и то у широким распонима: од шетње, боравка у крчми и на балу, па до излета, путовања и боравка у великом свету.

У опису приватног живота Срба у Хабзбуршком царству XVIII века Тимотијевић ипак није полазио ни из чега. У Предговору својој књизи он изричито указује на оне ауторе чији радови су му помогли у извођењу нових задатака, а ти аутори су: Васа Стајић, Мита Костић, Тихомир Остојић, Радослав М. Грујић и Душан Ј. Поповић. Уз то он наглашава да није тежио „расветљавању једне појаве са становишта различитих дисциплина, колико усаглашавању са поукама студија културе као свеобухватне дисциплине“ (Тимотијевић 2006: 12). Такво усредсређење на историју културе представља веома плодну оријентацију, која у великој мери спасава аутора од неплодности детаљних, често крајње тричавих расправа о феномену приватности, а поготово у околностима реалне опасности извлачења теме изван оквира емпиријских датости у којима се о предмету може аналитички утемељено разговарати и истраживати. Када то кажемо, имамо на уму чињеницу да се и сам Аријес, на почетку свог програмског текста, запитао „да ли је уопште могућа историја приватног живота?“, 5 а онда је пажљивим разматрањем дошао до реалне основе и релативно стабилног упоришта за могућу сазнајну, аналитичку процедуру. У том рафинираном излагању најчвршћа тачка и јесте управо историја културе, у којој многа опажања која се односе на историју приватног живота добијају своја дубинска значења и смислове. Истовремено, у оквиру оваквог концепта ранији сазнајни домети, попут Остојићевог истраживања живота монаха у фрушкогорским манастирима (Досийеј y Хойову, 1907), Грујићевих описа српског школства (Срйске щиколе 1718-1739, 1908), Стајићевих новосадских породичних историја (Новосаgске биоірафије, 1936-1956), Костићевих расправа о специфичностима српске грађанске културе (Досийеј Обраяовић у истиоријској иерсиекеииви ХVIII и ХІХ века, 1952) или Поповићевог описа живота српског народа на тлу Војводине (Сpби y Војвоgини, 1957-1963), дошли су до пунога изражаја.

Разлику између ових ранијих, позитивистички вођених и усмераваних истраживања, с једне, и ових садашњих резултата српских историчара културе инспирисаних француском школом Филипа Аријеса, није тако тешко успоставити. Ако су ови ранији истраживачи описивали поједине сегменте друштвеног, културног живота Срба, они су то чинили са намером да дају

${ }^{5}$ Видети нав. текст у Аријес - Диьи 2002: 5. 
детаљну емпиријску слику на основу које је, утврђивањем непобитних чињеница, било могуће сагледати како фактографску комплексност друштвене ситуације тога времена тако и системе претпостављених узрочности који су до такве ситуације довели. Тимотијевић, међутим, приступа са знатно више потребе да семиотички организује сопствена сазнања и да дође до класификационе прегледности на основу које је могуће уочавати процесе дугога трајања у једном, за Србе преломном времену када су из оријенталне цивилизацијско-културолошке сфере ушли у окциденталну, тј. западно / средњоевропску. Све то је драгоцено као очигледан резултат европеизације и модернизације српске културе, па се ова сазнања не своде само на потребу за што ширим кругом емпиријских чињеница него је реч о културно-семиотичком систему са знатно обухватнијим, системским пољем дејства у области друштвених и хуманистичких наука. То поље дејства не подразумева само деловање на друге науке него подразумева и спремност на усвајање оних сазнања која долазе из неких претходних времена и, чак, наизглед превазиђених методолошких концепција. Таква свеобухватност и спремност на синтезу без ограничења представља несумњиву врлину Тимотијевићеве студије Рађање модерне йривайностии.

О судару јавног и приватног, али још и више о сукобима унутар јавног сектора око вођења државне и друштвене политике сећања написао је Мирослав Тимотијевић једну изузетно важну књигу: Таковски устианак-Срйске Цветии: Ојавном зајеgничком сећаюу и заборављаюу у симболичкој йолийици званичне рейрезенйайивне кулйуре (Бгд 2012). У тој књизи, која представља очигледан пример четвртог Тимотијевићевог теоријско-методолошког обрасца, аутор се позабавио начином успостављања сећања на велике историјске догађаје везане за почетак Другог српског устанка и за велико историјско дело Милоша Обреновића. Око основног места од којег су кренули важни историјски догађаји, око Таковског грма, испреплетен је читав чињенични низ који је на државном и друштвеном плану систематски градила јасно профилисана визуелна, симболичка култура, те читава културна политика и политика сећања српскога друштва, те младе српске државе у настајању и развоју. Та култура и политика сећања је расла онако како је расла и моћ династије Обреновића, па је кнез Милош 1836. године овај дан прогласио општенародним празником: „Био је то први празник вазалне Кнежевине, званично посвећен обележавању почетка борбе за слободу, а општенародно прослављан под популарним називом Српске Цвети“ (Тимотијевић 2012: 11). Током владавине Обреновића овај празник се „налазио у средишту историјског сећања симболичне политике званичне репрезентативне културе“ (Тимотијевић 2012: 12), али је с падом те династије, тј. после Мајског преврата 1903. започела деконструкција таквог културног догађаја највишег државног значаја. Задуго је тај чин био гурнут у систематски заборав, а онда је с раскрајањем социјалистичког интернационализма поново светковина Таковског грма била стављена у жижу културне јавности. Описујући детаљно све ове процесе, аутор је водио начелну расправу о феноменима културе и 
политике сећања, те о улози државних и јавних функција које укидају сваки спонтанитет у овим догађањима.

Са студијом Таковски устианак-Срйске Цвейи Мирослав Тимотијевић је не само начинио специфичну „студију случаја једног од средишњих меморијских топоса званичног јавног заједничког сећања“ него је и отворио још једно теоријски и методолошки засебно подручје свога истраживања: друштвени живот организован по начелима уметности постао је легитимна сфера интересовања овог историчара уметности. Строго узев, у догађањима око Таковског грма и није реч о уметности у ужем смислу него пре свега о некој врсти друштвеног спектакла организованог око историјско-политички препоручљивих догађаја и прихватљивих идеја. Сва та догађања Тимотијевић је тумачио са становишта једне шире друштвене и политичке семиотике, тј. семиотике српске културе у којој појединачни знакови активирани унутар сложеног друштвеног и идеолошког спектакла носе недвосмислене политичке поруке и очигледно пропагандно дејство.

Тимотијевићева студија случаја Српске Цвети настала је у оквиру већ поменуте, опште слутње и замисли „нове културне историје“, а она је заснована на флексибилној и динамичкој „повезаности емпирије и теорије. Било би лакше писати историју меморијског топоса по принципу традиционалне историографије, у којој би се низале кључне личности и преломне ситуације, као што би било релативно једноставно протумачити га кроз апстрактну теоријску схему. Однос емпирије и теорије нисмо схватили механички, као употребу једног одређеног теоријског модела погодног за структурално сређивање грађе, њен опис и тумачење. Приклонили смо се уверењу да се теорије могу најбоље развијати кроз студије конкретних феномена у контексту њихове историјске променљивости“ (Тимотијевић 2012: 14). У овом, теоријско-методолошком погледу потраге за моделима тумачења у оквиру „нове

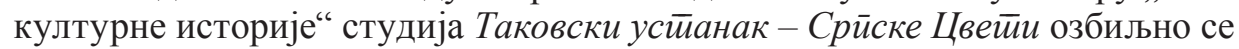
наслања на искуство рада на књизи Манасӣир Крущиеgол, али по систематизацији феномена јавности и приватности, она се итекако ослања и на студију

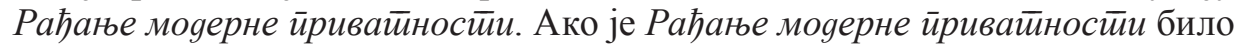
у знаку одбране индивудуума од државне присиле, сада је у књизи Таковски

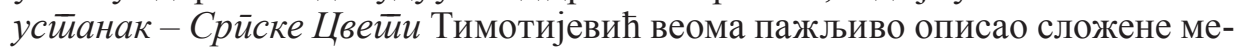
ханизме деловања државних структура на свакога појединца понаособ и на друштво у целини, и то у домену деловања тзв. меке моћи, те указао на то како се промишљеном политиком сећања непосредно утиче на обликовање менталног склопа националне и државне, друштвене и културне заједнице. Из тих разлога ове две студије из семиотике српске културе непосредно допуњавају једна другу: чак се чини да тешко можемо реконструисати значај сваке понаособ уколико их не посматрамо у семиотичком склопу целине коју граде на тако специфичан и занимљив начин.

3. ТЕРминолошкА исклизнућА. У овој фази напуштања стриктног подручја историје уметности и посезања за простором семиотике и историје 
српске културе Мирославу Тимотијевићу ће се десити неколико карактеристичних терминолошких исклизнућа која сведоче и о дубљим недоумицама са којима се аутор, по свему судећи, суочавао. И одмах треба то изричито рећи: решења за која се он определио нису она најбоља која су му стајала на располагању. Читав низ недоумица отворио се, очигледно, Мирославу Тимотијевићу током рада на књизи Рађање моgерне йривайносиии, која је, као што је већ речено, објављена 2006. године. Своју претходну књигу, Срйско барокно сликарсивво, Тимотијевић је објавио десет година пре тога, а у тој књизи он није имао крупнијих дилема у вези са тим каква је црквена уметност, каква национална култура и какво народно биће у оквиру којег су свој опус остваривали сликари о којима он пише. Такво одређење националне културе и народног бића није, дакако, нимало сметало да се реализује и нужност сагледавања сложених односа са свим уметничким, културним и социјалним кодовима са којима су поменути црквени сликари имали некакве блиске релације. Напротив, такво слагање појмова и ширих концепата темељно је доприносило да се јасно сагледају сложене релације између, с једне стране, сликарско-техничке спреме и академског познавања уметничког заната, a, с друге стране, специфичности догматско-теолошке и еклесиолошко-литургијске праксе, темељних питања народнога бића, као и национално-грађанског конструисања идентитета читаве културе и свеукупног друштва у којем се ова ликовна дела појављују као супстанцијално важна. Дакле, разликовање појмова народа, нације, културе, уметничких техника и кодова, друштвених и државних прилика чинило је основ за јасније сагледавање свих ових, веома сложених концепата и њихових међусобних релација.

Шта се, међутим, десило у Тимотијевићевој књизи Рађање моgерне

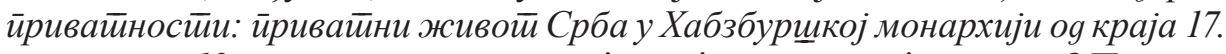
gо йочетика 19. века и какву мрежу појмова је аутор у њој изградио? Пре свега, треба уочити да појам народа, тј. српскога народа, у овој студији више не бива помињан него је системски истискиван. Наместо тог старог и прастарог, али врло прецизног и оперативног појма појављује се његов грчки пандан 'етнија' и 'етнос', што би у основи требало да значи исто или врло слично што и реч 'народ'. Али, као што је то у сваком језику добро знано, две различите речи никада не значе исто, а међу различитим речима које претендују на исто значење увек се, пре или касније, испостави некакав моменат разлике који утврђује извесну семантичку посебност у поступцима дистрибуције значења тих речи. Другачије речено, две речи истих семантичких претензија почеће временом да значе понешто различите ствари, а управо тај чинилац разлике постаће значајан за начин разумевања основног феномена на који поменути термини упућују. Може се, дакле, рећи да у семантичком простору неког језика веома ретко се појављују прави и потпуни синоними, а међу синонимним речима по правилу постоји нежна и ситна диференцијација значења због којих се, временом, семантичка разлика почиње све јасније успостављати. Због свега тога се и може рећи да потпуних синонима заправо нема: разлика се јавља макар на нивоу конотативних ако 
не баш и денотативних аспеката језичког знака, па се у том конотативном простору веома често почињу зачињати и неке темељније, денотативно тврђе постављене разлике.

А да је и сам аутор јасно перципирао ове аспекте семантичке дистрибуције језичког знака, доста очигледно сведочи начин на који је обавио ове замене речи и термина, а посебно како је то сам спровео у оквиру индекса имена и појмова који на крају књиге резимира кључне речи читаве студије. Од самих почетака своје књиге Тимотијевић готово редовно користи синтагму 'српска етнија', а системски елиминише израз 'српски народ'. Ова промена, међутим, не представља тек обичну замену речи и термина него она садржи веома озбиљне импликације које, чак и денотативно, доста другачије именују, па и концептуализују сам феномен који је предмет изучавања. Кад користимо реч 'народ', ми тиме дискретно сугеришемо неколико важних конотативних аспеката језичког знака. С једне стране, та реч имплицира чин рађања као начин на који народ настаје: треба се не само родити, него би тог рађања требало да буде у знатној мери тако да можемо рећи како се и 'народило' свих оних бића која се рађају унутар једне шире заједнице. Реч 'народ', дакле, указује на суштинску сродност, тј. припадност истом роду свих људи који сачињавају један народ. Сви ти људи, наиме, себе сматрају делом исте, дубинске сродности.

С друге стране, јасно је да у једном народу нисмо, строго узев, сви баш у пуном сродству, али сопствени народ фигуративно видимо као заједницу блиских бића, као некакву, алегоријски речено, проширену породицу: то мора бити скуп особа довољно блиских да им се можеш са емотивном топлином обратити традиционалним речима: „Браћо и сестре“. Уколико ове топлине уопште има, онда има довољно унутрашњих разлога да тај народ као народ опстане; тачније, има довољно енергије да се за опстанак те и такве заједнице неко бори и избори. Уколико такве топлине нема, уколико се припадницима сопственог народа не можеш пунога срца обратити речима: „Браћо и сестре“, онда ту разлога за опстанак такве заједнице више нема, па тај опстанак ни трансцендентне силе неће подржати, а поготово неће сами људи који су део те заједнице. Људи из такве заједнице која је сасвим изгубила центрипеталне силнице, увек су на путу да постану нешто сасвим друго и нешто што до тада они нису били. Кључ спасења је у њима самима, али је тај кључ негде сасвим затурен, а нико нема ни вољу ни жељу да тај спасоносни кључ потражи.

Реч 'народ’ садржи још једну, веома озбиљну импликацију, а она је повезана са сродном речју која је код Срба, али и других Словена, од самих искона народног живота коришћена за означавање скупине људи повезаних пре свега комуникацијском блискошћу. Реч је о старословенској речи 'єАзыкъ', која је означавала не само најсавршеније средство комуникације и њену системску уређеност (језик, у данашњем, структурално-комуникацијском значењу речи) него је означавала и људску скупину, заједницу (народ или нација, у данашњем значењу речи) која је око таквог средства комуникације 
организовала своје постојање. У том смислу је Словенима, уколико следе менталну матрицу својих искона, сасвим примерено да не стварају своје народне целине негде изван задатог језичког простора, а језик ће им поставити основу на темељу којег ће концептуализовати опстанак сопствене заједнице. Само у ређим случајевима, углавном пред изазовима спољашњих чинилаца, словенски народи су тежили да распростру своје постојање и на просторе који им језички не припадају, а то је долазило до изражаја онда када су ти народи под одређеним историјским околностима падали у искушење империјалног деловања: трајније је таквим искушењима подлегао превасходно онај највећи, руски народ. Тако нешто се у средњовековној историји Срба само једном десило у озбиљнијем и доследније изведеном облику, а везано је за амбиције цара Душана да направи империју која би била наследница Византије, царевине у то време већ изложеној озбиљним дезинтеграционим процесима. Таква настојања цара Душана су изазвала велике несреће у српском народу, па никакво чудо што у канону српске православне цркве од Немањићких владара једино цар Душан није стекао статус светости. Људи релативно плитке памети лако могу бити засењени војно-политичком моћи цара Душана, али људи дубље духовне памети такво површно блештавило могу само презрети.

У сваком случају, појам народа је и у далеким, средњовековним временима подразумевао релативно високу меру уређености језичке, књижевне и културне заједнице, па се чини да је само коришћење термина народ и те како имало смисла и семантичког оправдања. Због тога у српској ентологији и етнографији, када се она развила на вуковским и цвијићевским темељима, није било неопходно терминолошко враћање на изворне грчке термине и изведенице из лексичког корена 'ethnikos', а стабилизовани су како традиционални термини народ и народни тако и модерни појмови нација и национални. Два блиска, али понешто различита значења која обележавају две различите фазе у историјском развоју неке етничке целине, покривена су у довољној мери појмовима народа и нације. Истина, у српској етнологији и етнографији постојао је још један термин који је, по наглашеном степену неуређености етничке целине, био несумњиво инфериоран у односу на термине народа и нације: тај термин је означен сложеницом 'етничка маса', а он обележава оне неуређене заједнице које нису јасно утемељиле своје народно биће, па су се оваквим заједницама, без већих тешкоћа, могла истовремено наметнути врло различити, понекад чак и противуречни народни или национални идентитети. На јужнословенском простору су још од средњег века као стари народи који су стекли своју идентитетску основу сматрани Бугари, Срби и Хрвати, док су сви остали задуго остали у развојној фази етничке масе која је могла водити различитим исходима.

Тако је, дакле, мишљење о овим сложеним процесима, који су имали својих реперкусија и у сфери историје језика, историје књижевности, историје уметности, историје цркве итд, с много разлога рачунало с појмовним низом: етничка маса - народ - нација. Напустити овакву, веома сложену, 
рафинирану и довољно прецизну скупина појмова и термина, значило је, просто, кренути погрешним путем и отворити мисаоне процесе који воде ка разбијању озбиљно утемељене етничке, народне, националне и културне самосвести. То је, истовремено, значило да је требало сопствени народ и културу лишити већ изграђеног мисаоног упоришта које делује веома подстицајно у погледу одбране опстанка читавог народа, а онда се таквим лишавањем отворити ка неким, крајње неизвесним процесима са још неизвеснијим исходима. Поменута терминолошка тријада је савршено ефикасна и прецизна у именовању процеса и развојних етапа у тим процесима, па би зарад научне ефикасности ту тријаду требало безрезервно очувати.

Насупрот томе, од своје књиге Рађање моgерне йривайностии: ииривайни

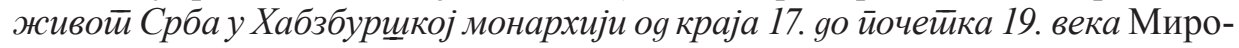
слав Тимотијевић је покушао ову терминолошку тријаду да замени бинарним терминолошким системом. Тај је систем сачињен од термина етнија и нација: ова два термина су суфиксално уједначена, што је добар показатељ да треба да делују као део истог система означавања. Очигледно је, исто тако, да би појам етније требало да одговара како појму етничке масе тако и појму народа, што је извор озбиљних слабости будући да су појмови етничка маса и народ два веома различита појма, те да заслужују да се јасно именом, терминолошки разликују. Никако није добро када се неки научни термини појављују како би замаглили представе о реалности коју треба да опишу, а у овом случају можемо само и искључиво о замагљивању реалности говорити. Да се прецизност у именовању различитих аспеката ове осетљиве стварности желела очувати, онда би и унутар терминолошког система било неопходно очувати управо термин Volk (народ) који ваља разликовати од етничке масе која нема супстанцијалну уређеност какву има Volk (народ). У том смислу је појам Volksgeist (Дух народа) довољно садржајан и прецизан, па је као такав итекако потребан сваком облику научног сазнања које би тежило утемељености и проверљивости сопствених увида. Појам Volksgeist-a (Дух народа) супстанцијално је чврсто утемељен и као такав неопходан сваком сазнању које би претендовало на поузданост и какву-такву објективност.

Поменути појам Volksgeist (Дух народа) утемељен је и као део система појмова који конституишу читаву област знања у знатно ширем проблемском обиму, а та област је покривена тријадом појмова као што су: Volksgeist (Дух народа), Zeitgeist (Дух времена) и Weltgeist (Anima mundi, Дух света). Тај систем потврђује да појам Volksgeist не може бити ваљано схваћен и дефинисан уколико не буде прожет чиниоцима појмова Zeitgeist и Weltgeist, a једино у јединству, које подразумева довољно јасну разлику између појединачних чланова овог система, можемо доћи до ваљаних одређења, увида и сазнања. Или како то на једном месту вели Хегел: „Сами принципи народних духова у нужној поступности само су моменти једног опћега духа, који се помоћу њих у повијести уздиже и довршава себе у тоталитет, који себе схваћа“ (XEГЕл 1951: 85). То значи да никада озбиљна, научно утемељена размишљања и сазнања у вези са Духом народа не могу бити начињена а да се не укрсте 
са увидима у Дух времена и Дух света. Тим и таквим укрштањима могу се избећи различити облици парцијалних увида и застрањивања какви се неретко умеју наметати из одређених интелектуалних или политичких центара моћи, често и са агресивношћу која је застрашујућа.

Није ни прилика ни место на којем бисмо могли ући у детаљније разматрање ове и овакве проблематике, али је евидентно да је читав поменути појмовни систем добио изузетно добру и садржајну разраду како у домену философије тако и у домену различитих наука који улазе у простор филолошког, али и шире друштвено-хуманистичког проучавања. Философска сазнања у распону од Готфрида Вилхелма Лајбница, Һамбатиста Вика, Шарла Луја Монтескјеа, Волтера, Дејвида Хјума, Георга Вилхелма Хегела и др., као и сазнања у области проучавања народа и њихових култура у распону од Карла Фридриха Мозера, Јохана Готфрида Хердера, Вука Караџића, Јозефа Добровског, Павла Јозефа Шафарика, Јована Цвијића и др., учинили су да је појам Духа народа постао врло садржајан, научно утемељен и сазнајно проверљив, а уз то и ширим склопом појмовног система добро изграђен у широким оквирима тоталитета људскога знања. Чињеница да је било веома спорних учења која су водила разним облицима расистичке дискриминације, није сведочила о слабости оваквог теоријско-методолошког облика сазнања, него је сведочила пре свега о разним облицима злоупотребе зарад позиције моћи и изградње онога што називам империјалном епистемологијом. Није ту кривица самог метода него је кривица у злоупотреби метода, па се међусобним сучељавањем различитих становишта, чисто научним критеријумима сазнања морала исцртати критична граница између науке и манипулације научним сазнањима, између употребе и злоупотребе. На тај начин се могао извести сазнајни, научни обрачун с поменутим облицима манипулације и злоупотребе. Заменом једног доброг и поузданог метода некаквим другим методом, далеко мање добрим и поузданим, могу се само створити нови облици злоупотребе науке и научног сазнања, а да се почетни проблем неће сам по себи решити. Уз то ти нови облици злоупотребе могу само довести до још ужаснијих последица по цео људски род и његов свет.

Учинити такву терминолошку замену тријадног појмовног система бинарним системом, па то спровести у области проучавања српске културе, књижевности и уметности нема неког нарочитог смисла: таквим поступком се у квалитету мисаоних операција ништа не добија, а може се и мора се прилично тога изгубити. Ово свођење тријаде на бинарни модел имало би, наиме, само лоше мисаоне последице и доста неугодне консеквенце, јер се сложени и дуготрајни историјски процеси свакако мање успешно могу приказати употребом два него употребом три, значењски изнијансирана појма. Та три појма су, дакле: етничка маса - народ - нација, а наместо ове тријаде Мирослав Тимотијевић се опредељује за бинарни систем: етнија - нација. Слабости овог једноставнијег, бинарног модела су садржане у чињеници да се дуготрајни процеси настанка нација не могу објаснити тек тако једноставним прелазом из етније и нацију: много успешнији модел тумачења садржан 
је у појмовној тријади која може веома садржајно и тачно да испрати оне главне фазе у обликовању прво народног, а потом и националног бића. У случају Срба и јужних Словена све те процесе треба сагледавати и структурно-историјски описивати током временског распона од средњега века па до наших дана.

Врлине и мане ова два терминолошка решења лако бисмо могли исказати на једном, довољно сложеном примеру који може да покаже како су настале три јужнословенске нације. Од тих трију нација два су стара словенска народа: Срби и Бугари. Из широке словенске етничке масе у средњовековном периоду су се ова два народа доста јасно издвојила и постигла садржајну и неспорну идентификацију, а она почива колико на двама, довољно различитим језицима који су се почели издвајати из заједничке словенске основе, толико и на различитим облицима политичке, државотворне, црквене, књижевне и културне свести, те одговарајуће праксе. Стога ваља описати процес настајања српске редакције старословенског језика од краја XII века и издвајања нечега што можемо и морамо звати старосрпским језиком, са одговарајућом писменошћу и књижевношћу, а тим догађањима је претходио и пратио их процес настајање српске државе са светородном лозом Немањића. Оно што је томе претходило, бар од IX века, о чему постоје, истина штури, али ипак довољно јасни чињенични подаци, све то је врло значајно, али није имало снагу успостављања народног бића и његовог идентитета. $\mathrm{У}$ то исто време се сличан процес дешавао и Бугарима, с тим што су они своју државу успешније обликовали у периоду пре изразитог јачања Немањића током XIII и посебно XIV века. За то време су Бугари углавном слабили, а после битке код Велбужда 1330. они су потпуно изгубили на значају. Снага српске државе је, међутим, потрајала све до Косовске битке 1389, а потом је непрестано опадала, некако се одржавјући и током трајања деспотовине, све до пада Смедерева 1459. И Срби и Бугари су се, дакле, у средњем веку успешно издвојили из словенске етничке масе, па су већ тада они неспорно постали два блиска, али посебна народа.

То се, међутим, не може рећи за Македонце који су далеко најдуже опстали у статусу етничке масе. Језички ближи Бугарима, а државно-политички и културно-историјски Србима, они су задуго остали негде између: посебан народ нису постали, а непрестано су се ломили између бугарске и српске целине, не могавши до краја да припадну ни једном ни другом корпусу, а истовремено партиципирајући и у једном и у другом. Како је настанак модерне српске и бугарске нације био процес који се испољавао највише током XVIII и XIX века, евидентно је да су и у том периоду Македонци и даље остајали у фази етничке масе. Тако се процес развлачио без коначног решења све до XX века, када су Македонци најзад, под вођством комунистичке идеје о разбијању великих народа и нација, одлучније започели са креирањем сопственог националног идентитета. У тако вођеном процесу десило се да су Македонци из статуса етничке масе или супстрата одмах 
кренули у процес изградње нације, а да при том нису могли дефинисали какав су то народ они претходно били.

У сваком случају, бинарни модел етнија - нација може бити погодан за објашњење настанка нација веома слабог идентитета, какав налазимо код Македонаца, али је тај модел сасвим непогодан за објашњење настанка нација јаких идентитета, а то су нације које су претходно имале развојну етапу посебног народа попут Срба и Бугара. За овај други, темељније укорењен случај једино прихватљив модел мишљења је онај који почива на тријадној схеми: етничка маса - народ - нација. Уколико се, пак, тај мање рафиниран и ефикасан, бинарни модел тумачења настанка неке нације узима из емпиријског амбијента идентитетски слабих етничких творевина, онда је савршено јасан мотив за такву терминолошку редукцију, тј. свођење са тријадне на бинарну релацију. Мотивацију треба пронаћи у чињеници да се историјско време, тј. епоха када се овакве теорије почињу ширити и представљати као једино исправан начин разумевања ових сложених процеса, не случајно поклапа са радикалним облицима глобалистичке идеологије која се, по правилу, сама проглашава за становиште које хоће да превазиђе димензије строго националног, идеолошког начина мишљења.

Другим речима, у времену глобализације за империјалну епистемологију врло је функционална замисао да се сви национални иденитети прикажу као сасвим скорашњи, крхки феномени који углавном зависе од изградње самосвести не пре XVIII века, па је за познавање ових процеса довољно знати само оно што се на креирању идентитета чинило током XIX, XX, а поготово XXI века. Наравно, при том се прикрива једноставна чињеница да све што је тако младо и скорашње, крхко и слабашно лако може да нестане или да се претвори у нешто сасвим друго и суштински другачије. Такве поставке по којима су народи и нације само супстанце подложне лаком преобликовању, сасвим одговарају империјалној епистемологији сачињеној по стратешким замислима центара моћи који владају глобалистичким светом, али не одговарају самим народима и нацијама који треба да буду пуки објекти ових процеса. Још кад се све то повеже са чињеницом да су поједини народи, у дугом, вишевековном контиунитету, били изложени разним облицима религијског, политичког, економског, пропагандног, медијског, па и војног рата, онда се погубне последице по елементарно саморазумевање и самопоштовање тих народа могу и морају непосредно рефлектовати и у домену основне стратегије тих народа у погледу како данашње одбране сопственог бића тако и изградње темеља њиховог будућег опстанка.

Све ово о чему говоримо, током два последња века се на један врло драматичан начин непосредно рефлектује у пољу саморазумевања Срба и њиховог настојања да обезбеде начине сопственог опстанка. Због свега тога се у мисаоном систему једног просечног српског интелектуалца, а то значи оног који је образован по строго окциденталистичким, западним системима знања, системски убризгаван облик тумачења по којем Срби за настанак свог колективног идентитета треба да буду пре свега усмерени ка историјском 
хоризонту новог века и почетка грађанског друштва. Читав средњи век се веома често с нехајношћу препушта забораву, а питање настанка везује превасходно за XVIII век и улазак у западноевропски културни модел из претходног, византијског и православног културног обрасца. У склопу оваквог начина мишљења редовно се јавља и презир према целокупном византијском наслеђу, а тиме се у српску православну културу уноси један изразито католички и крсташко-мисионарски став који, узгред буди речено, има веома слабу културно-историјску основу, те доста неубедљиву интелектуалну аргументацију. Његова основа је пре свега садржана у милитаристичкој, империјалној и пљачкашкој страсти која је западне центре моћи редовно водила у сусрет са новим световима као увод у нова освајања и нове начине пљачке и експлоатације. То, међутим, што таква теза чињенички лоше стоји, не значи да пропагандно не може да се прошири много више него што здрави разум и ваљани облици мишљења то могу да поднесу. Отуда се, по врло сложеној схеми, у нашем времену код Срба, а поготово у вези с питањем елементарног саморазумевања Срба и српског питања, тако очигледно и пропагандно оркестрирано исказују модели мишљења засновани на недвосмисленом и злоћудном „духу самопорицања“, о чему на уверљив начин сведочи Мило Ломпар у својој драгоценој студији. ${ }^{6}$

4. СЕМИОТИЧКА ДЕСКРИПЦИЈА И ВОљА НАРОДА ЗА ТРАЈАњЕМ. Мирослав ТИмотијевић, дакако, не подлеже суштински овој патолошкој форми названој „духом самопорицања“! Он са дубоким поштовањем уочава, анализира и тумачи уметничке, културне и животне феномене који испуњавају семиотички простор српског друштва XVIII века, тако да ту можемо препознати пре свега напор који води ка потврђивању, дубљем разумевању и афирмацији свих феномена о којима је истраживачки умео да посведочи. Но, упркос свему томе, а поготово упркос многим истраживачким доприносима српских друштвених и хуманистичких наука, данас, а то значи бар век и по, пре свега на нивоу површинских слојева свести изложених ефектима озбиљног културалног рата који се против српске аутентичне културне самосвести води, врло је распрострањено уверење да су Срби један од новијих европских народа, неспособних да се одупру дејствима великих и старих народа света. Овакав начин мишљења јавља се искључиво код оних који не умеју да разликују појам српског народа и појам српске нације, а самим тим нису у стању да сагледају исконске дубине до којих српски народ својом културно-историјском и духовном свешћу допире.

Стога је одиста крајње време да се представе о српским духовним, културним и историјским вертикалама поставе у прави, реални оквир, а то је немогуће уколико се не држимо тријадне схеме: етничка маса - народ - нација. Своје идентитетске процесе српски и бугарски народ су обавили још у средњем веку, и то далеко најуспешније од свих јужнословенских народа.

\footnotetext{
${ }^{6} \mathrm{O}$ томе видети, треће, допуњено издање поменуте књиге: ЛомпАР 2012.
} 
Хрвати су у том погледу приметно заостајали, а Словенци поготово, који су тек од времена прихватања протестантизма средином XVI века започели да граде и креирају свој верски и национални идентитет. Македонци су, као што је већ речено, далеко заостајали у том погледу, а о амбицијама неких Бошњака и Црногораца, те о успесима и неуспесима таквих настојања исказаних у XX веку, биће доста речи и у деценијама које долазе. У вези са овом сложеном проблематиком, терминологија и концептуални оквири никада неће моћи да буду сасвим уједначени, јер су и различити приступи појединих етничких маса, народа и нација веома различити, па је природно да они од свога приступа неће лако одустати.

Српски научници немају ни један једини ваљан разлог да одустану од тријадног терминолошког решења, а то је стога што они треба да се дубински загледају у оне најстабилније и идентитетски најјаче основе сопственог постојања. У том погледу они су упоредиви са најстаријим народима света који су прошли не само кроз фазу етничке масе, него су преко фазе традиционалног народа дошли и до фазе модерне нације. Онако како то важи за најстарије и најдуготрајније народе света (Грци, Италијани, Французи, Немци, Енглези, Руси, Јевреји, Египћани, Индуси, Кинези и др.), а то су све народи са развијеном религијском свешћу, са моћном митологијом и духовном традицијом, тако би то требало да важи и за Србе, за њихов начин сагледавања сопственог опстанка и трајања у датом времену и простору. Такви народи који не само што имају дуге духовно-историјске континуитете, него исказују и недвосмислену вољу за опстанком и трајањем, такви народи треба да послуже Србима као концептуални параметри, па и основ за терминолошка решења која дефинишу сазнајне процесе о овим осетљивим феноменима.

Имајући све ово на уму, остаје доста нејасно зашто и како се Мирослав Тимотијевић одлучио за терминолошка решења која му нису омогућавала најпоузданији модел сазнања истраживаног предмета. Неки разлози би могли лако да буду наведени јер се намећу готово сами по себи, а у склопу једног парадоксалног закључка да се ове слабости Тимотијевићевог концепта појављују на готово истим местима и из готово истих разлога који су одлучивали и о појавама његових врлина. Пре свега, она врлина коју смо назвали „теоријском и методолошком ширином“, несумњиво је допринела да Тимотијевић непрестано, а у поменутом случају очигледне збрке - готово грчевито трага за новим концептуално-терминолошким и дискурсно-аналитичким решењима чак и у оним областима у којима нема разлога за велике недоумице и забуне. Тај грч се посебно осетио на оним местима где се испољила ауторова потреба да мало освежи традиционалну појмовну и терминолошку апаратуру, те да прихвати нека решења која делују донекле освежавајуће и, наизглед, традицијом сасвим неоптерећено. Свакако пожељена и драгоцена потреба за теоријским новинама учинила је да, у једном специфичном и осетљивом тренутку, Мирослав Тимотијевић покуша да традиционалне, добро 
опробане термине замени некима за које је претпоставио да би могли бити ефикаснији, али такве претпоставке сасвим сигурно нису биле оправдане.

Уз ту потребу за откривањем теоријских иновација, треба још додати и чињеницу да је основни подстицај за овакво терминолошко преименовање дошао од изразитих критичара савремених појавних облика национализама, који су поготово од 90-их година XX века, трагали за теоријским и терминолошким решењима који ће корене етничке, народне и националне самосвести учинити крајње условним и хипотетичним, па у том смислу и саме људске заједнице крхкијим и мање зависним од облика сопствене културне самосвести. Ти и такви теоретичари, попут Бенедикта Андерсона, Антони Смита, Ричарда Џенкинса, Томаса Хилана Ериксена и др. ${ }^{7}$ доносили су неку врсту релаксације крајње неуралгичних питања, па се Тимотијевићу могло учинити да оваквим преформулацијама и сам даје ваљане доприносе да се превазиђу националистички типови мишљења и дискурса, те да се неутралише погубно дејство радикалне националистичке идеологије и њој примерене политичке праксе. Можемо само претпоставити да се њему учинило да је синтагма српски народ у тој мери већ набијена емфатичким доживљајима (како позитивним тако и негативним, зависи од тачке гледишта), да је веома тешко заузети релативно неутралну, чисто научну тачку гледишта како би се могло доћи до сазнања сасвим објективних, прихватљивих чак и оним супротстављеним групацијама које негују сасвим супротне и противуречне емфатичке доживљаје.

Сасвим су разумљива оваква очекивања, али није баш разумљиво то што је уместо наводно непожељног терминолошког решења понуђен један, без сумње, мање ефикасан и аналитички мање оперативан терминолошки модел. А бинарни модел етнија - нација је свакако и мање ефикасан и мање оперативан од тријадног модела етничка маса - народ - нација. Он је такав jep, једноставно речено, природа увида у генезу феномена нације је крајње мањкава и недостатна, па у том смислу недовољност и непрецизност увида не могу бити добри помоћници чак ни у покушајима да се неутралише рђаво дејство национализама у савременим политичким приликама и неприликама. Јесте да овакав приступ, условно речено, може себи да дозволи строго сцијентистичка амбиција везана за проучавање српске уметности и културе XVIII века, али сваки шири захват у истраживану грађу захтевао би да се јасније сагледају временске димензије које сежу све до средњега века, а у том домену поменути бинарни терминолошки модел постаје крајње неефикасан и сасвим немушт. Утолико је чудније како то да се Мирослав Тимотијевић, управо у склопу тимског рада који је сагледавао целину српске историје од средњега века до данашњих дана, није током истраживачког рада довољно прибрао, те на време схватио да је склизнуо у терминолошке ино-

${ }^{7}$ О томе видети студије: Андерсон 1990; Смит 1998; Џенкинс 2001; Ериксен 2004. и др. Истовремено, у сврху сагледавања сложености ових и оваквих процеса, ваља пажљиво прочитати и зборник ХоБСБАУм - РеЈНџеР 2011. 
вације које га много више ограничавају и чине несигурним него што му шире и утемељују сазнајне видике.

Тај бинарни терминолошки модел, сасвим сигурно, више производи нових проблема него што решава неке од старих, добро познатих мука и недоумица. Шта све то конкретно може да значи, лако би се дало наслутити, па и закључити, кад би се само пажљивије претресао појмовни регистар

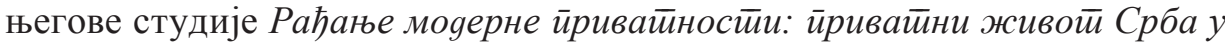
Хабзбуршккој монархији оg краја 17. gо йочейка 19. века. Попис појмова је већ, сам по себи, занимљив као својеврсни концептуални оквир неопходан за потпуније разумевање целокупне проблематике ове студије. У оквиру Индекса ове књиге читалац, наиме, може наћи читав низ појмова који описују људске склоности, друштвене односе и конвенције, норме понашања, вредносне обрасце и сл. Тако се ређају појмови као што су: алкохолизам, аскетизам, балови, батине, везе, воће, графике, гробови, двор, дворци, десерт, емоције, забране, задовољства, задужбине, закони, затвори, игре, идентитет, идеологија, иконе, имовина, индивидуалност, институције, јавна сфера, језик, казне, књиге, књижевност, колачи, конвенције, кочије, кревети, култ, култура, купање, куповина, кухиње, љубав, милосрђе, милостиња, младост, мода, модернизације, молитва, морал, мошти, музика, навике, накит, намештај, наследство, новац, норме, обичаји, образовање, огледала, одећа, оружје, парохија, патриотизам, песмарице, песме, пећи, пијаце, писање, писма, пића, побожност, погреби, подрум, подушја, пожар, поклони, понашање, пороци, портрети, порцелан, пост, посуђе, пошта, поштовање, правила, празници, привилегије, пријатељство, природа, причест, просветитељство, проституција, просторије, протоколи, путовање, рад, разговор, разум, рат, ред, резиденција, реформе, ритуали, рођење, ручак, самоћа, сатови, свакодневице, свете тајне, сексуалност, село, сервиси, симболи, смрт, собе, срамота, сребро, становање, станови, старост, стереотипи, суд, тело, тестаменти, трговина, увреде, удаја, удружења, улице, универзитет, хералдика, хигијена, ходочашће, храна, штедња, шуга исл. Ту је и читав низ појмова који непосредно означавају људска или животињска бића, поједине професије, друштвене слојеве и класе, места друштвених окупљања и дешавања: аристократија, бабице, бербери, бећари, библиотекари, болесници, браћа, верници, вештице, владари, војска, газда и газдарица, гимназије, гости, гостионица, град, грађанство, дом, деца, држава, друштво, духовници, ђаци, жене, живот, животиње, калфе, кафане, конзисторије, кројачи, крчме, кувари, кумови, куће, лекари, личност, мајка, мајстори, манастири, монаси, омладина, отац, официри, племство, поданик, покајник, породица, послуга, радници, разбојници, родбина, родитељи, салони, сахране, свадбе, свекрве, светитељи, свештеници, сељаци, сестре, синови, сиротиња, сликари, слуге, спахије, сталежи, становништво, старешине, странци, студенти, супружници, суседи, таст, трговци, тутори, удовице и удовци, укућани, учитељи, фризери, хајдуци, цехови, црква, чиновници, шегрти, школа итд. 
У Индексу, одиста, има много тога, па је сам попис веома индикативан и користан у читању ове драгоцене студије. Ипак, на том списку нема основног појма који све те емпиријске форме држи на окупу: нема категорије народа! Али, исто тако, нема ни термина као што су етнија или етницитет, као његових семантичких замена које се у самом тексту ове студије, по правилу и са беспрекорном тачношћу јављају. Зашто су изостављени термини етније и етницитета није лако одговорити, али се део одговора крије управо у чињеници да је аутору студије за емпиријски опис „приватног живота Срба у Хабзбуршкој монархији од краја 17. до почетка 19. века“"важан читав систем појмова помоћу којих он покрива емпиријску ширину истраживаног феномена, али да се упркос свему томе он неће питати: а каква је концептуална промена настала у самом основном појму, у народу, о којем је реч? Одговор би се могао пронаћи у чињеници да управо емпиријска ширина свега онога што је приватни живот српског народа представља примарни истраживачки циљ аутора ове драгоцене студије, а да при том он нема потребе да обави додатни поглед на значење и смисао основног појма. Зато је и могао да се деси теоријски-методолошки неопрез уз чију помоћ је аутор олако примио онај бинарни терминолошки модел уместо тријадног који је, без сумње, знатно примеренији самом предмету сазнања. Уколико у средиште пажње ставите искључиво оно емпиријско обиље које се да препознати у Индексу ове студије, онда вам се одиста може учинити како између бинарног и тријадног терминолошког модела и нема велике разлике. Тако се може објаснити порекло и појава овог, мање ефикасног сазнајног терминолошког решења, као и лакоћа са којом је у Тимотијевићевој студији оно истиснуло бољи и успешнији теоријски и терминолошки модел.

Истина, у Индексу студије Рађање моgерне ирривайностии Мирослава Тимотијевића јављају се појмови нације, националног идентитета, осећања, деловања и националне свести, али ови појмови свакако нису довољни да покрију свеколику сложеност свеукупног културно-историјског и духовног трајања Срба на Балкану, у Средњој Европи и Медитерану. Кад се, пак, погледа садржај ових појмова и сам начин на који је тај садржај аутор конструисао у својој студији, онда се може видети како је ту изостајало свако јасније, супстанцијалније одређење у оним пољима у којима је такво одређење одиста постојало: православно-хришћански, светосавски идентитет, митско-историјски поглед на свет, свест о фолклорном обрасцу, Косовски завет, представе о културно-историјским континуитетима и сл. У том погледу је слика српског народног идентитета у Тимотијевићевој студији остала крајње нејасна и флуидна, а наместо тога је описан читав систем разлика, иновација које су, у оквиру процеса модернизације, европеизације и вестернизације Срба, требало да допринесу лакшем и потпунијем уклапању читавог народа ('етније') у политичке и цивилизацијске оквире Хабзбуршког царства. Другим речима, ова студија није ни тежила да утврди како се српски народни идентитет развијао и мењао остајући у понечем исти, а у понечем се прилагођавајући политичком, социјалном, културалном амбијенту Хабзбур- 
шког царства у оквиру којег су потражили спасоносно окриље и заштиту. Она емпиријска ширина какву препознајемо у Индексу јесте ипак била примарни циљ ове драгоцене аналитичке расправе.

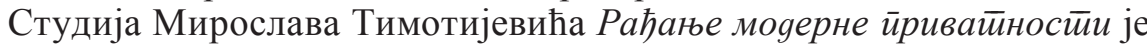
помно описала многобројне промене које је процес модернизације подразумевао, а у томе је садржана њена драгоцена сазнајна снага и домет. Суочена са огромним емпиријским обиљем, ова драгоцена студија је обликована попут оних дела које о много чему расправљају, али не дефинишу са довољно прецизности или не дефинишу уопште, централни, средишњи појам чијим се појавним облицима баве. Примера ради, на разним језицима света сам прегледао одиста велики број речника књижевних термина, а немали број таквих приручника садржи читав низ одредница који се тичу књижевности, њених појавних облика и разноврсних аспеката њеног проучавања, а истовремено са тог списка веома често је изостајао управо сам појам књижевности. Ово специфично Тимотијевићево терминолошко исклизнуће у доброј мери ме подсећа на овакве случајеве. Ипак, треба рећи и то да је овде реч о поменутом примеру најбоље врсте који се да замислити: драгоцени и високо компетентни прилози изврсно доприносе да основни појам буде сагледан из мноштва различитих, аналитички прецизних углова, а онда се, након свих описа и аналитичких процедура, појави темељна несигурност око основног разумевања средишњег појма око којег се читав сазнајни поступак и води. Чак се намеће и дискретни закључак како је свака прича о идентитету само нека врста терета која у историјским, цивилизацијским менама јесте искључиво сметња, а од њега, од идентитета, никакве користи заправо нема. Овакав закључак свакако није ни исправан, а ни озбиљније утемељен у случају српског народа и његове идентитетске слике, па није исправан ни утемељен и у случају ове веома важне студије Мирослава Тимотијевића.

И да закључимо, увођење појмовног пара етнија - нација није од користи за проучаваоце сложених народних, идентитетских и културно-историјских прилика на јужнословенском простору: од тога немају користи не само проучаваоци историје уметности него ни проучаваоци историје књижевности, драме, позоришта, музике, историје културе у најширем смислу, а поготово то важи за политичке, војне, друштвене и многе друге типове историографских расправа. Од ове бинарне терминолошке структуре користи могу да имају само они који би желели да прикрију сложеност феномена и да не сагледају свеколику специфичност генезе неког народа и потом неке нације. Такво концептуално становиште које покрива бинарна релација етниja - нација подешена је према оним националним традицијама чије дубине нису нарочито велике и чији конститутивни процеси су извођени не само свесно и плански, са много сазнања о поступцима креирања идентитета, него и са свешћу да све то и може и не мора бити, те да се може читава конструкциона игра мењати како прилике то налажу, а допуштено је чак и измишљање традиције и националног иденитета. Другим речима, тзв. младе 
нације, оне лишене дубљих корена, а поготово оне које су своје корене морале индивидуалним напорима да савладавају, па и креирају и чак измишљају, представљају плодно тло за овакву теорију са одговарајућим, површински заснованим терминолошким решењима. Томе треба додати чињеницу да су главни добитници ипак негде изван самих, тако креираних нација, а налазимо их у разним центрима државне, војне, политичке, економске, финансијске, медијске и др. моћи који обликују процесе глобализације света: у тим и таквим процесима судбина малих, младих и нејаких нација није ништа друго него утапање у једну велику мелтинг-пот стратегију нестајања свих специфичности оних народа и култура које немају аутентичне, унутрашње снаге и које - по логици империјалне епистемологије - зато и треба да нестану.

Појам етније нам тихо сугерише да су сви народи света млади, нејаки и без корена, те да сви треба да нестанемо са својим колективним, културним идентитетаима. У строго политичком смислу, профит од оваквих концепата у области историје, социологије, антропологије и других дисциплина треба да понесу они којима је стало до глобализационих процеса и њихових контролних пакета на разним странама света. Другим речима појмовни пар етнија - нација јесте истински израз империјалне епистемологије и одговарајућих типова дискурса који имају озбиљних амбиција да креирају, контролишу и преусмеравају конститутивне процесе тзв. малих нација. Стога за сваку друштвену и националну заједницу која нема амбиција да напросто нестане, врло је корисно да благовремено истакну озбиљне резерве према теоријским и методолошким типовима дискурса који не уважавају најснажније, најчвршће конститутивне елементе који утврђују различите типове колективитета, па и одговарајуће ставове научне и интелектуалне заједнице која те ставове треба да легитимише.

У овој изградњи специфичног облика империјалне епистемологије и одговарајућих типова научног дискурса учињен је један темељни гест којим се релативно стабилна тријадна структура претворила у прилично крхку и хипотетичну бинарну структуру. То је учињено тако што је управо најтврђи ослонац у промишљању ових процеса не само доведен у питање него је и сасвим искључен из теоријске схеме и, по свему судећи, проглашен идеалистичком конструкцијом наместо које су испостављени још крхкији и нестварнији критерији. Реч је о појму Volksgeist-a, тј. Духа народа, који је и научним истраживањима током XIX и прве половине XX века бивао једино супстанцијално одређен појам: тај појам је утемељен и као философска категорија (Хегел), али и као филолошка (Хердер, Вук и др.) и етничка (Цвијић и др.) категорија која се може научно објективно, системски врло прецизно, прегледно и емпиријски проверљиво изложити тако да се свакој нацији, уколико има озбиљну супстанцијалну основу, може одредити идентитетски темељ, па тиме и проверити колико је тај темељ теоријски и емпиријски одржив. Уколико јесте одржив, тј. уколико постоји озбиљна и проверљива етничка и народна супстанца, онда се на тој основи, уз деловање 
још неких додатних критеријума, може објективно говорити о конститутисању нове нације. Уколико тога нема, онда је боље и мудрије на таквом конституисању нове нације не инсистирати јер би се тиме проблеми само умножавали, а не би се решавали.

Са увођењем бинарног модела, са позиције етничког супстрата одмах ce, без додатних провера, може поскочити до нивоа нације, што значи да са системски гради илузија како је процес формирања нација веома лако обавити: довољно је само имати јак интерес неког великог, моћног политичког и војног, економског и идеолошког центра, па ће такав процес моћи без већих препрека да се креира и реализује. Уместо супстанцијалне основе коју подразумева етнички супстрат, а поготово народ, сада се испоставља празан појам, а тај празан појам могу попунити сасвим тричаве, безсадржајне, узгредне и случајне одреднице. Другим речима, као основа за формирање оваквих концепата нације у времену глобализма не подразумева се више никаква озбиљна супстанцијална основа него се испоставља голо ништавило, празнина, категоријални нихилизам, а најчешће је довољна искључива воља јаких центара политичке, војне, економске и идеолошке моћи и њихова спремност да процесе скривено или нескривено воде ка одређеном циљу, а то пре свега значи да су вољни да све те испразне и залудне процесе финансирају. Тако створене, крхке нације имају разлог постојања негде изван саме себе, па ће трајати само дотле док ти разлози изван њих самих буду делотворни. Такве нације су производи других, страних сила, па ће настати, постојати и нестати искључиво по вољи тих спољашњих сила. У тим и таквим нацијама ништа не постоји по њима самима, па нико неће зажалити када такве нације нестану са историјске сцене.

Срби не припадају, или не би требало да припадају таквим народима који чезну да постану објекат туђе воље и да највероватније нестану, па зато не би требало ни да негују њима непримерене концептуалне и терминолошке поставке од којих неке нарочите сазнајне користи неће задобити, а имаће велику штету. Срби су као народ, па и нација конститутисани по унутрашњим, властитим правилима, на супстанцијалној основи коју су сами градили и изградили, па тај процес јесте превасходно ствар њиховог историјског сазревања и конституисања на основу критеријума које су сами успостављали и за њих преузимали историјску одговорност. Треба, међутим, истаћи да помињани стари народи, са којима Срби треба дијалошки да граде како сопствену садашњост тако и заједничку, глобалну будућност, имају на располагању и нека друга, врло ефикасна средства у напорима да се неутралишу рђави ефекти како сопственог национализма тако и национализама других народа. У тим напорима неутрализације рђавих аспеката национализама лоша је услуга уводити старе народе у аутодеструктивну летаргију и самозаборав не би ли се осветљавали само новији процеси у оквиру којих млађи, новији народи не би осећали неку врсту комплекса инфериорности. И у овој проблематици свакако би требало да важи правило да је од највеће важности да се може и уме изрећи истина ствари, а само на таквој истини треба 
градити оне културолошке и цивилизацијске циљеве који се током историје људског рода испостављају као израз дубинских неминовности времена, тачније Духа времена који је наступио. Насупрот деловању империјалне епистемологије, Срби, а и сви други народи са аутентичном идентитетском основом, имају на располагању елементарна људска права да јасно артикулишу своју истинску вољу за трајањем и опстанком у временима која долазе. Све су то озбиљни разлози због којих тријадни систем појмова етнички супстрат - народ - нација никако не треба да буде елиминисан и замењен бинарним моделом етнија - нација.

5. ЗАОКРУЖЕњЕ НАУЧНОГ ОПУСА. Када се, после дуге и тешке болести, 2016. године окончао биолошки циклус Мирослава Тимотијевића, знало се да тиме није заокружен читав његов опус, те да ће уследити извесне допуне. Истина, само су најбољи познаваоци Тимотијевићевог опуса знали којих ће размера те допуне бити, а такав један зналац, Тимотијевићев докторант и наследник на Катедри за историју уметности Филозофског факултета у Београду, проф. др Владимир Симић, у име Матице српске опростио се са заслужним научником некрологом објављеним у Pagy Mā̄uще срӣске за 2020. годину. Мирослав Тимотијевић је дуго био и остао везан за Матицу српску и њене установе. Члан сарадник Матице српске постао је 1991, а стални члан сарадник 1995; члан Одбора одељења за ликовне уметности је био од 1995. па до смрти, а дужност секретара Одељења обављао је 1999-2008; члан Извршног одбора и Управног одбора Матице српске био је 1999-2008, а за члана Савета Матице српске изабран је 2016. У Галерији Матице српске Тимотијевић је био председник Надзорног одбора 1992-2009, председник Управног одбора 2009-2016, а на почетку XXI века дао је одиста велики допринос новом програмском обликовању свеукупне делатности Галерије.

О једној књизи, већ поодмаклој у настајању у временима Тимотијевићевог тешког боловања, па и његовог прераног одласка са овога света, добро се знало бар у установама са којима је овај зналац радо, активно, пуним срцем сарађивао - у Галерији Матице српске и Матици српској. Реч је била о студији о Теодору Крачуна, која је предвиђена да пропрати и репрезентативну изложбу радова овог водећег српског сликара XVIII века. Та се књига под насловом Teоgop Крачун (Галерија Матице српске - Покрајински завод за заштиту споменика културе Војводине, Нови Сад 2019) одиста и појавила, три године после ауторове смрти. Овом књигом је Мирослав Тимотијевић значајно попунио једну празнину у свом научно-монографском скупу, па је додатно заокружио сопствени опус озбиљном историјскоуметничком студијом о једном великом сликару барока, епохе којој је највише истраживачке пажње посветио. Таква једна обимна, теоријски утемељена и истраживачки доследно изведена монографија управо му је недостајала, премда је он 1993. магистрирао на опусу једног Теодора Илића Чешљара, али је после тога теоријски и методолошки искушавао различите облике истраживања, да би се на крају свог живота поново вратио једном великом сликару и проблему 
тумачења његовог дела. Таква монографска форма посвећена једном великом сликару можда му је и једино недостајала да би он проблемски заокружио сопствени опус.

И у овој књизи је итекако видљива теоријско-методолошка ширина Тимотијевићевог приступа, те плодоносно јединство чврсте документаристичке, чињеничке основе, коју је он допуњавао доследним, теоријски утемељним облицима интерпретације и луцидне херменеутике засноване на дубинским теолошким увидима пре свега. То обједињавање нечега што има пандан у културолошким истраживањима широког спектра, а што се често именује као нови културни материјализам, као и нечега што почива на дубинским моделима разумевања и тумачења уметничког текста, представља сјајан спој какав се може пронаћи и у неким облицима истраживања других, сродних облика стваралаштва, па и у области књижевности, на пример. У том смислу поново, али сада са нешто јаснијом, већ изложеном аргументацијом, истичем закључак да истраживачки немири Мирослава Тимотијевића нису само релевантни за област историје уметности него имају много ширу релеванцију и у домену различитих друштвених и хуманистичких дисциплина. Тим пре је било неопходно истаћи шта у свим Тимотијевићевим трагањима и лутањима јесте подстицајно, општеприхватљиво и крајње убедљиво, али и оно шта није ни на који начин прихватљиво, те шта би се могло оценити чак и као неуспешно. То што овај први скуп чинилаца изразито доминира, а што се овај други скуп појављује на неким, наизглед дискретним, али нимало наивним местима, чини Тимотијевићев опус изузетно значајним, али и повремено трновитим и поучним. Тај је опус многоструко изазован и подстицајан, ваља га и у будућности изнова читати и тумачити, а извесна неугодна искушења и чак неуспеси само ће додатно потврђивати његову пуну ваљаност и сазнајну убедљивост бар у оним, изразито доминантним доменима у којима је она потпуно очигледна. У сваком случају Мирослав Тимотијевић је створио одиста моћно и значајно научно дело, а то дело тек очекују нови читаоци и нове авантуре тумачења и проучавања. Када се једном буде писала свеобухватна семиотика српске културе, научни доприноси Мирослава Тимотијевића ће у тој синтези имати итекако значајно, драгоцено место.

\section{ЦИТИРАНА ЛИТЕРАТУРА}

Андерсон, Бенедикт. Нација: замищиљена зајеgница. Ната Ченгић и Наташа Павловић (прев.). Загреб, 1990.

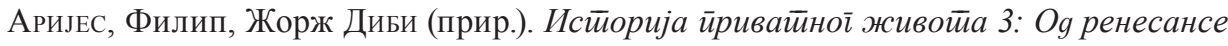
gо йросвећеностии. Група аутора. Роже Шартије (ур.). Љиљана Мирковић (прев.). Београд: Клио, 2000.

БАрт, Ролан. Смрт аутора. Сувремене књижевне йеорије. Мирослав Бекер (прир.). Загреб: СНЛ, 1986. 


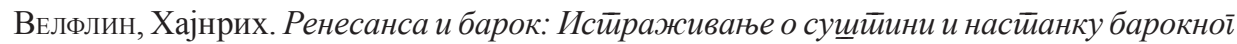
стиила у Ийалији. Бранка Рајлић (прев.). Сремски Карловци - Нови Сад: Издавачка књижарница Зорана Стојановића, 2000.

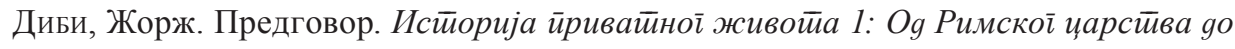
1000. іоgине. Група аутора. Филип Аријес, Жорж Диби (прир.). Љиљана Мирковић (прев.). Београд: Клио, 2000.

Ериксен, Томас Хилан. Ейницийийе и национализам. Александра Бајазетов Вучен (прев.). Београд, 2004.

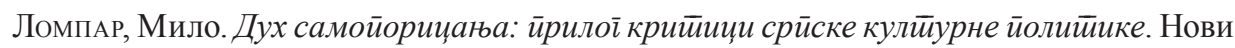
Сад: Орфеус, 2012.

Смит, Антони Д. Национални ияенӣийеӣ. Слободан Ђорђевић (прев.). 1998.

Тимотијевић, Мирослав. Сремски деспоти Бранковићи и оснивање манастира Крушедола. Зборник Майице срӣске за ликовне умейносӣи 27-28 (1991-1992).

Тимотијевић, Мирослав. Црква свет̄й Георйја у Темищвару. Нови Сад: Матица српска, 1996а.

Тимотијевић, Мирослав. Срйско барокно сликарст̄во. Нови Сад: Матица српска, $1996 б$.

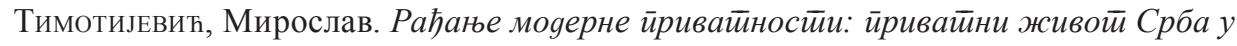
Хабзбуршкој монархији оg краја 17. gо йочейка 19. века. Београд: Клио, 2006.

Тимотијевић, Мирослав. Манасӣир Круще gол 1-2. Нови Београд - Нови Сад: ИК „Драганић“- Покрајински завод за заштиту споменика културе Војводине, 2008, књ. 1.

Тимотијевић, Мирослав. Таковски устианак-Срйске Цветии: о јавном заједничком

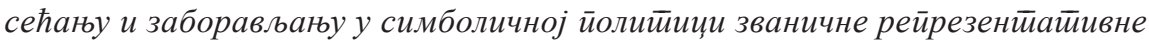
кулйуре. Београд: Историјски музеј Србије - Филозофски факултет, 2012.

Флоренски, Павле. Со земље. Мирољуб Авдаловић (прев.). Београд: Логос, 2004.

ХегЕл, Георг Вилхелм Фридрих. Филозофија йовијестии. Виктор Д. Зоненфелд (прев.). Загреб: Култура, 1951.

Хобсьаум, Ерик, Теренс Рејнџер (ур.). Измищљљағе ӣраquщије. Слободанка Глишић и Младена Прелић (прев.). Београд, 2011.

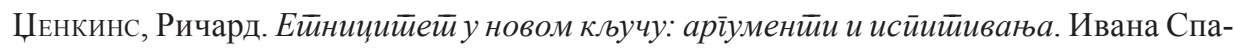
сић (прев.). Београд, 2001.

Ivan Negrišorac

INVESTIGATIVE UNREST AND TEMPTATIONS OF MIROSLAV TIMOTIJEVIĆ: TOWARDS THE SEMIOTICS OF SERBIAN CULTURE

\section{Summary}

The author analyzes the scientific opus of art historian Miroslav Timotijević and establishes the relevance of this opus for the wider set of social sciences and humanities, especially for the semiotics of Serbian culture. He questions this scientific opus within 
various problem and theoretical-methodological fields which Timotijević opened up in an extremely interesting and provocative way in separate phases of their development. One circle of his studies comprises monographs on Serbian churches and monasteries (St. George's Church in Timisoara, 1996; Krušedol Monastery, 2008) and in that respect Timotijević follows the basic ideas of Pavel Florensky on the semiotic complexity of churches and monasteries, but he also takes into consideration the earlier contributions of Serbian scientists in this domain (Veljko Petrović, Milan Kašanin, Vojislav J. Đurić, Dejan Medaković, Vojislav Korać etc.), as well as the findings of the modern science of art. The second circle refers to the historiographical synthesis in the study of Serbian baroque painting (Serbian baroque painting, 1996), while his approach is prominently theoretical, poetic and iconographic, even with some elements of that type of stylistic analysis that can be connected to Heinrich Wölfflin's idea of an artistic history 'without names'. The third circle is connected to researching the history of daily life and privacy in the Serbian culture of the $18^{\text {th }}$ century (Birth of modern privacy: Private life of Serbs in the Habsburg Monarchy from the end of the 17th until the beginning of the 19th century, 2006), which places this art historian, along with his precious contribution, among those Serbian historians who sought the investigative paths and programmes of Philippe Ariès and Georges Duby. After that book, however, Timotijević started choosing terminology that cannot be assessed as a progress in the study of a sensitive issue of the creation of peoples and nations: a more traditional concept that implies the triad of the concepts 'ethnic mass', 'people', and 'nation' is, the author of the paper believes, much more appropriate and operational than the binary model of 'ethos' and 'nation' that Timotijević completely adopted. The first triad model is more adequate for the age which strives to preserve the diversity of the world, while the second binary one is more appropriate for an age that strives to unify the world and cancel the beauty of diversity for which the age of globalism has no more sensitivity. The fourth circle is connected with the culture and politics of memory and Timotijević wrote a specific case study regarding the celebration of the holiday Serbian Palm Sunday (The Uprising of Takovo - Serbian Palm Sunday: on common public remembrance and forgettance in the symbolic politics of the official representative culture, 2012), which shows how state politics establishes not only the phenomenon of remembrance but also of forgettance within a representative culture of a social community. And, finally, the fifth circle covered by Miroslav Timotijević with his monographs refers to the study of the opus of a great painter of the baroque period (Teodor Kračun, 2019), the age to which this valuable researcher devoted the majority of his research attention. In all these fields this art historian discovered anew the hidden possibilities of innovation and progress of theoretical-methodological forms of thinking. Because of that, especially because of the knowledge he unearthed with his research, Miroslav Timotijević occupies an important and valuable place in a comprehensive semiotics of Serbian culture.

Матица српска

Матице српске 1, 21000 Нови Сад

stanicnegrisorac@gmail.com 